
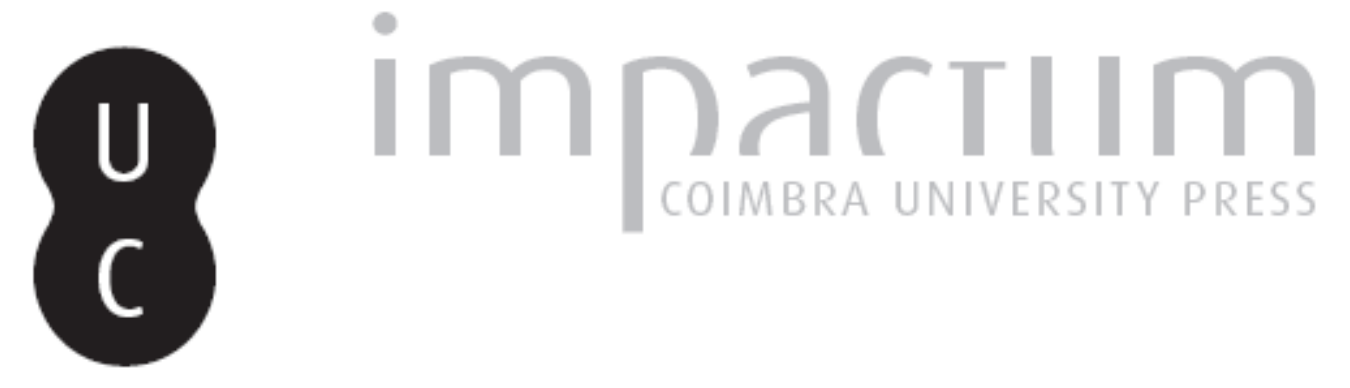

\title{
Sobre o território e a sede dos Lancienses (Oppidani e Transcudani) e outras questões conexas
}

\author{
Autor(es): $\quad$ Guerra, Amílcar \\ Publicado por: Faculdade de Letras da Universidade de Coimbra \\ URL \\ persistente: \\ URI:http://hdl.handle.net/10316.2/37750 \\ DOI: \\ DOI:http://dx.doi.org/10.14195/1647-8657_46_8 \\ Accessed : $\quad$ 26-Apr-2023 13:44:08
}

A navegação consulta e descarregamento dos títulos inseridos nas Bibliotecas Digitais UC Digitalis, UC Pombalina e UC Impactum, pressupõem a aceitação plena e sem reservas dos Termos e Condições de Uso destas Bibliotecas Digitais, disponíveis em https://digitalis.uc.pt/pt-pt/termos.

Conforme exposto nos referidos Termos e Condições de Uso, o descarregamento de títulos de acesso restrito requer uma licença válida de autorização devendo o utilizador aceder ao(s) documento(s) a partir de um endereço de IP da instituição detentora da supramencionada licença.

Ao utilizador é apenas permitido o descarregamento para uso pessoal, pelo que o emprego do(s) título(s) descarregado(s) para outro fim, designadamente comercial, carece de autorização do respetivo autor ou editor da obra.

Na medida em que todas as obras da UC Digitalis se encontram protegidas pelo Código do Direito de Autor e Direitos Conexos e demais legislação aplicável, toda a cópia, parcial ou total, deste documento, nos casos em que é legalmente admitida, deverá conter ou fazer-se acompanhar por este aviso.

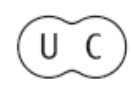




\section{CONIMBRIGA}

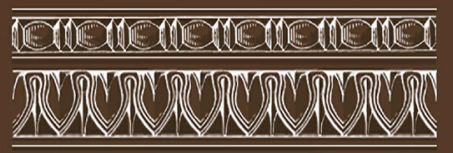

INSTITUTO DE ARQUEOLOGIA

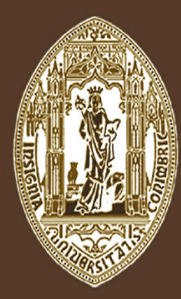

VOLUME XLVI - 2007

FACULDADE DE LETRAS UNIVERSIDADE DE COIMBRA 
AMÍLCAR GUERRA

Faculdade de Letras da Universidade de Lisboa

Investigadorda UNIARQ. amilcarguerra@fl.ul.pt.

SOBRE O TERRITÓRIO E A SEDE DOS LANCIENSES

(OPPIDANI E TRANSCVDANI) E OUTRAS QUESTÕES CONEXAS

"Conimbriga" XLVI (2007) p. 161-206

RESUMO: No âmbito da investigação sobre povos e lugares do mundo pré-romano e romano do Ocidente hispânico, os problemas relativos aos Lancienses da Lusitânia constituem um dos tópicos que originaram mais ampla discussão e maior diversidade de propostas. Na sequência de um conjunto considerável de intervenções arqueológicas na Beira Interior, perspectivaram-se novas hipóteses e estabeleceu-se já, com bases sólidas, a identificação da sede dos Lancienses Transcudani com os vestígios subsistentes no sítio do Mileu, Guarda, cujos fundamentos aqui se sintetizam e reforçam. Reanalisando a documentação atinente aos Lancienses Oppidani, enunciam-se as razões da sua identidade com os Ocelenses e sistematizam-se os argumentos que sustentam a sua localização no território correspondente, de forma aproximada, à Cova da Beira. Por outro lado, reinterpretando-se os restos materiais descobertos na chamada Torre de Centum Celas e sua envolvência, aponta-se este lugar como a sede desta última entidade.

ABSTRACT: Issues related to the Lancienses of Lusitania rank among the most discussed and interpreted topics regarding research on peoples and places of the Pre-Roman and Roman world in Western Iberia. Following considerable archaeological surveys and excavations in the Portuguese region of Beira Interior, new hypotheses have been raised that solidly identify the remains extant at the site of Mileu, in Guarda, as the capital of the Lancienses Transcudani. In this paper, we synthesize and strengthen the grounds on which this new interpretation is based. Having reviewed the sources concerning the Lancienses 
Oppidani, we give reasons for identifying them with the Ocelenses and provide systematic arguments in favour of their location in the territory that approximately corresponds to Cova da Beira. Furthermore we re-interpret the materials found at the so-called Tower of Centum Celas and its surroundings, indicating this place as the capital of this people. 


\section{SOBRE O TERRITÓRIO E A SEDE DOS LANCIENSES (OPPIDANI E TRANSCVDANI) E OUTRAS QUESTÕES CONEXAS}

\section{Introdução}

A identificação das entidades étnicas dos mundos pré-romano e romano e dos territórios e cidades por elas ocupados constituiu uma das preocupações da historiografia. Por isso, inventariar as antigas realidades geográficas da Península Ibérica, entre elas os nomes e localização no espaço dos povos antigos se afirmou como um objectivo específico de alguns trabalhos de grande alcance, em especial do projecto Iberische Landeskunde, lançado por Adolf Schulten (1955; 1957) e completado por António Tovar (1974; 1976; 1989).

Mais recentemente, a União Académica Internacional, através do seu Comité Espanhol, concretizou a sua parte do ambicioso projecto da Tabula Imperii Romani, de natureza idêntica, mas com uma diferente organização e um leque amplo de colaboradores, tarefa que se apresenta como uma actualização e ampliação da obra levada a cabo por aqueles dois investigadores. Infelizmente, circunstâncias concretas do desenvolvimento deste projecto ditaram que uma pequena parte do território hispânico, respeitante a TIR K-29, não fosse tratada, precisamente aquela em que se incluem as entidades que são objecto deste contributo.

No sentido de contribuir para o preenchimento dessa lacuna e pelo facto de uma das vertentes do trabalho que há alguns anos me ocupou (Guerra, 1998) se ter orientado para este domínio da investigação, retomam-se aqui algumas das ideias então expendidas, acrescentadas de novas reflexões que, partindo de uma base textual, confluem em problemas de geografia antiga e de organização político-administrativa desse território do Ocidente hispânico. 
Inicia-se a exposição com a análise da documentação de natureza literária e epigráfica a respeito de diversas entidades da Beira Interior, procurando completar o quadro com os dados de natureza arqueológica, conferindo-se uma especial atenção aos traçados viários pela importância que estes assumem no caso vertente.

O objecto essencial deste contributo diz, no entanto, respeito aos diversos Lancienses, "povo" que, no âmbito geográfico referido, mais concitou a atenção dos investigadores, talvez pelo conjunto de problemas que o tema suscita. O feixe de questões que o estudo destas entidades coloca tornou-se progressivamente mais complexo, graças a um amplo número de trabalhos a elas dedicados, entre os quais avultam as variadas análises que consagrou a este assunto Jorge de Alarcão (1988a; 1988b; 1988c; 1990a; 1990b; 1998; 2001, 2005a; 2005b; Alarcão e Imperial, 1996). Para além disso, a realização na Beira Interior de importantes trabalhos arqueológicos ao longo das últimas décadas, teve inevitáveis consequências neste domínio da investigação, cujos resultados mais sugestivos se podem encontrar na dissertação de mestrado de Helena Frade (2002), nas Actas do Colóquio "Lusitanos e Romanos no Nordeste da Lusitânia" e na dissertação de doutoramento que recentemente Pedro Carvalho (2006) apresentou à Universidade de Coimbra.

Há que ter consciência, em primeiro lugar, que uma abordagem destas questões deve assentar numa análise o mais ampla possível dos materiais de natureza diversa e que a fundamentação das hipóteses beneficia substancialmente se esses elementos de origem díspar parecerem concordantes. Por isso, manusear-se-ão, para além dos já referidos elementos de natureza arqueológica e epigráfica, alguns dados linguísticos, não apenas reportáveis ao mundo antigo, mas igualmente os que as realidades medieval e moderna proporcionam, com a convicção de que quase sempre se identificam elementos nestas épocas que remontam ao período pré-romano ou romano e podem ajudar a confirmar ou infirmar as diferentes hipóteses.

As considerações que se seguem resultam de uma prolongada reflexão e de uma postura crítica em relação a uma ampla massa de dados, originando em algumas circunstâncias uma rotura com a tradição. Este texto contribui essencialmente com uma nova interpretação para a muito debatida questão do território e da sede dos Lancienses Oppidani, que ponho à consideração da comunidade científica. 


\section{Os Lancienses da Lusitânia}

Pondo de lado os registos atinentes aos Lancienses que se incluem no âmbito dos Ástures, os autores clássicos referem uma única vez esse nome étnico de forma incontestável. Ocorre, em concreto, no famoso passo de Plínio (nat. 4,118) em que o enciclopedista latino faz o elenco de alguns dos oppida stipendiaria da Lusitânia. De qualquer modo, admitiu-se geralmente que essa entidade teria que ver com o topónimo

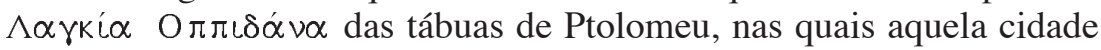
se incluía entre os Vetões, o que aumentaria as menções a ela concernentes.

Ao contrário, a segunda ocorrência do termo Lancienses, também ela documentada no mesmo passo da Naturalis Historia (PLIN. nat. 4,118), está há vários séculos envolvida em alguma controvérsia, que persiste até ao momento.

Depois de as mais antigas edições impressas aceitarem amplamente a sua repetição nesse parágrafo, a ideia foi recusada por uma parte dos editores modernos do texto pliniano, os quais, de uma maneira geral, não consideram viável essa hipótese. Apesar disso, a interpretação tradicional tem sido pontualmente admitida em fase recente, mais por razões histórico-epigráficas que de outra natureza, ganhando ultimamente alguns adeptos entre os investigadores que analisaram a questão dos Lancienses.

Esta hipótese assenta em argumentos atendíveis. Desde logo, tem a seu favor uma ampla tradição da crítica textual, que tem ponderado, ao longo do tempo, como interpretar o facto de alguns importantes manuscritos da Naturalis Historia registarem o mesmo nome uma segunda vez, na sequência Ocelenses Lancienses, que habitualmente separam por vírgulas. De uma maneira geral uma boa parte dos antigos editores deste texto, achando estranha a repetição de Lancienses, além do mais fora da ordem alfabética normal nesse elenco, propuseram uma solução habitual nas listas de Plínio, onde é frequente ocorrerem designações alternativas de povos, ligadas por qui ou qui et. Refira-se, a título de exemplo, que nesse mesmo parágrafo a enumeração de oppida se conclui com a sequência “/.../ Turduli qui Bardili et Tapori”.

A primeira opção, que segue uma importante tradição manuscrita, ocorre especialmente nas edições quatrocentistas ou de inícos de quinhentos, entre elas a impressa por Andrea Portilia (1481) ou as editadas por Ermolao Barbaro (1497) e Alessandro Benedeto (1507). A interpre- 
tação que prefere Ocelenses qui et Lancienses, forma que se impõe a partir daí, domina a ampla tradição editorial, sendo claramente majoritária no período correspondente aos séculos XVI a XIX: assim, a título exemplificativo, as edições de S. Ghelen (1539), J. Dalechamps (1587), Carl. Herm. Weisio (1841), I. Silig (1851) ou as impressas por Antoine Vincent (1553), Samuel Crespin (1615). Esta lição dos manuscritos reflecte-se igualmente em traduções como a de Philemon Holland (1601), É. Littré (1848-1850) e Bostock \& Riley (1855) e passa, naturalmente também para obras que recorrem a esses textos literários, como a de André de Resende (1593, p. 12), para referir apenas a que mais notoriedade ganhou entre nós.

Só mais recentemente, e acima de tudo em consequência do peso que assumiram neste domínio as edições de Detlefsen (1866) e a teubneriana de Mayhoff (1906), a maioria dos autores preferiu considerar que a repetição de Lancienses no mesmo passo deveria ser eliminada, por resultar supostamente de um equívoco no processo de transmissão textual, reduzindo-se, deste modo, uma ocorrência literária deste nome étnico.

Para a reabilitação da mais antiga tradição manuscrita entre nós contribuiu de forma decisiva a sugestão de Jorge de Alarcão (1990a, p. 369-370 e todos os seus artigos seguintes dedicados ao tema), seguida por outros autores (Guerra, 1995, p. 34-35, 111-112; Guerra, 1998, p. 559; Carvalho, 2006, p. 226). É preciso ter em conta, todavia, que as propostas editoriais que referimos (Ocelenses, Lancienses ou Ocelenses qui et Lancienses) devem ser corrigidas para Ocelenses Lancienses, a única que responde adequadamente às questões que se colocam e, simultaneamente, a que se ajusta à lição de um conjunto significativo de códices. As outras revelam-se impróprias: no primeiro caso introduz-se desnecessariamente pontuação entre os dois termos, subvertendo o sentido do texto; no segundo acrescenta-se qui et, o que, para além de carecer de fundamento em todo o processo de transmissão textual, confere um sentido completamente diferente a este passo. De facto, a utilização de qui ou qui et ocorre quando os dois termos são usados em alternativa, como acontece com Medubrigenses qui Plumbarii ou Turduli qui Bardili. No caso vertente, porém, os dois nomes só fariam sentido se usados em simultâneo, uma vez que corresponderia a uma designação bimembre, configurando uma situação equivalente à que se verifica com os Asturi Augustani e Asturi Transmontani ou os Celtici Praestamarci e Celtici Supertamarci. 
Como se verá mais adiante, é perfeitamente natural uma designação Lancienses Ocelenses ou a inversa, dada a necessidade de separar entidades conhecidas por nomes que se repetem com alguma frequência. E, acima de tudo, a mesma designação deveria ser, como propõe Blanca Prósper (2002, p. 110), a equivalente linguística de Lancienses Oppidani, bem documentada na epigrafia, mas, sublinhe-se, ausente dos textos clássicos.

A informação literária, todavia, não coincide exactamente com os registos epigráficos, circunstância que tem dado lugar a algumas controvérsias ainda não resolvidas. Em concreto, dispomos da informação proporcionada por um amplo número de monumentos inscritos, que documentam a seguintes realidades onomásticas:

- Duas referências genéricas aos Lancienses sem outra especificação: Lanciensis (Almeida, 1956, p. 160 n. 29 =HAE 1083), Idanha-a-Velha, Idanha-a-Nova (CB); terminus augustalis inter Lancienses et Igaeditanos, Vaz, 1977, p. 27-29, Peroviseu, Fundão (CB);

- Três atestações de Lancienses Transcudani: Lanc(iensis) Transc(udani), HEp 2, 36 (CIL II 5621), de Mérida (BA); Lancienses Transcudani, CIL II, 760, da ponte de Alcântara (CC); Lanciensis Transqudanus, EE VIII 112, Caldas de Vizela, Guimarães (BR);

- Nove ocorrências, sete das quais seguras, do nome dos Lancienses Oppidani: Lancienses Oppidani, CIL II 760, da ponte de Alcântara (CC); [La]nciensi Oppidan[o], FE 153; Lanc(iensi) Oppidanae, Almeida, 1956, p. 165, n. 36; Lancie $<n>$ si Oppidano, Almeida, 1956, p. 159 n. 27 = AEp $1961360=$ AEp 1967 147), as três atestações da Idanha-a-Velha, Idanha-a-Nova (CB); terminus augustalis inter Lanc(ienses) Opp(idanos) et Igaeditanos, CIL II 460, de Salvador, Penamacor (CB); Lanciensi Oppitano, AEp 1977 385, de Cáceres (CC); Lanc(iensis) Opp(idana), García Iglesias, 1973: 392-3, n. 184, de Mérida (BA); a de duvidosa restituição Lanc(ia)[Opp(idana)?], AEp 1985 541, Villalba, Villamiel (CC); a muito provável leitura e interpretação $L$ (ancia) O(ppidana) num marco miliário de Lameira, Belmonte (Belo, 1960, p. 41-44);

- Três registos da área, reportáveis aos Ocelenses: Arant[i]a Ocella[e]ca et Arantio [O]celaeco, Garcia, 1991, n. 11, Ferro, Covilhã (CB); um outro, de leitura difícil, e cuja relação com esta entidade é muito problemática, onde se atestariam os vicani Ocel[o]n[e]nses (FE, 69, 310.2; correspondentes a um vicus Ocelona - Fernandes et alii, 2006, p. 185-191), Ocel[e]nn[se]s (?) (Prósper, 2002, p. 109, de Ocelum) ou Ocellonienses (Alarcão, 2001, p. 315-316, de Ocelonia). 
Da análise global das informações de natureza epigráfica sobressai, em primeiro lugar, o facto de serem raros os casos em que o termo Lancienses ocorre isoladamente. Verifica-se, ao invés, que habitualmente os indivíduos identificam a sua proveniência apondo a este nome os qualificativos de Oppidani ou de Transcudani, mas nunca o de Ocelenses. Tal decorre, a meu ver, do facto de estas referências à origo corresponderem às entidades criadas pela própria administração romana, sintomaticamente as mesmas que se registam num documento de claro cunho oficial, a lista dos municipia que contribuíram para a obra da ponte de Alcântara.

De qualquer modo, estes dados não se compaginam com os que servem de base à lista pliniana, geralmente atribuídos às informações administrativas que podiam ser recolhidas em Roma. Neste contexto, poderia residir aqui a razão da discrepância entre estas duas fontes, que importaria resolver: Lancienses e Ocelenses Lancienses em Plínio, Lancienses Oppidani e Lancienses Transcudani nos documentos epigráficos.

A primeira solução consistiria em admitir que, não sendo estes dois elencos de entidades lusitanas exaustivos, houvesse, na realidade, pelo menos três designações distintas que envolvessem os Lancienses. Esta hipótese implicaria, mesmo assim, aceitar a correspondência entre o registo isolado do naturalista e uma das ocorrências da inscrição alcantarense, uma vez que, em boa verdade, estamos perante quatro conjugações distintas. A divisão tripartida dos Lancienses encontra-se sobretudo expressa nas várias reflexões de Jorge de Alarcão sobre o tema, em alguns casos acompanhadas de dúvidas mais ou menos declaradas (Alarcão e Imperial, 1996; Alarcão, 1998a, p. 146-147; 1990, p. 369-370; 2001, p. 295-299; 2005, p. 123-128).

Uma das objecções mais significativas a esta interpretação reside no facto de não se registarem os Lancienses Ocelenses entre os municipia que participam na obra da famosa ponte, quando o seu território se situaria, de acordo com as diferentes propostas, precisamente no âmbito dos restantes povos aí mencionados (Guerra, 1998, p. 480; Alarcão, 2005, p. 127-128; Carvalho, 2006, p. 227). Pedro Carvalho procura encontrar diversas justificações para o facto, tomando como seguro que nem todas as entidades existentes "entre Tejo e Douro" aí se encontram mencionadas, o que é verdade, por razões bem conhecidas. De facto, só se registam nessa placa as que são servidas por um conjunto determinado de vias, sendo insustentável, a meu ver, que algumas fossem 
dispensadas do contributo pela sua dimensão ou "menor peso ou influência institucional no quadro das civitates da região", ou ainda por terem colaborado de outra forma (Carvalho, 2006, p. 227). Penso, ao contrário, que o contributo para a obra da ponte, como determinação de uma entidade político-administrativa superior, teria de ser de natureza obrigatória e geral, isto é, atingia de igual forma todas as entidades beneficiadas por ela.

Para além disso, a abundante informação epigráfica relativa às indicações de origo das entidades em análise permite assinalar que em nenhum caso se reporta explicitamente um Ocelensis. Como já sublinhou Jorge de Alarcão (2005, p. 128) não deixa de ser sintomática e relevante essa ausência, ainda que a força probatória seja algo limitada, uma vez que reside essencialmente na constatação de uma carência de registos que, em última análise, poderia futuramente vir a ser colmatada. Importa não perder de vista que comprovar a inexistência dos Ocelenses como entidade autónoma num qualquer momento do domínio romano pode ser tarefa quase impossível se se pretende que ela se sustente em documentos inequívocos e válidos para diversas épocas.

$\mathrm{O}$ que parece claro, pela própria documentação subsistente, é que a criação das duas entidades dos Lancienses ocorre no principado de Augusto, uma vez que a epígrafe de Salvador corresponde necessariamente a um período em que essas duas realidades administrativas já existiriam. Todavia, o terminus augustalis de Peroviseu faz crer que, na realidade, nem sempre a própria documentação oficial indicava, de forma clara, a qual delas se reportava.

Para além das considerações expendidas acima, veio Blanca Prósper (2002, p. 110, nota 23) contribuir com uma sugestão muito relevante na análise deste caso: que o termo latino oppidum corresponderia à palavra *okelo-, como se sabe não exclusivamente hispânica ${ }^{1}$. Deste modo, tornar-se-ia extremamente viável que os Ocelenses Lancienses de Plínio correspondessem aos Lancienses Oppidani da epígrafe em questão, tal como sublinha também Fernando Curado (no prelo).

Esta possibilidade ganha ainda maior consistência com o facto de no território que lhes respeitaria (Ferro, Covilhã) se assinalarem

1 Parece relevante, como ficamos a saber por correspondência trocada com Fernando P. Curado (no prelo) que já M. de L. Albertos, profunda conhecedora destas questões, tenha já sugerido idêntica aproximação destes nomes, a qual, infelizmente, acabou por não ser divulgada. Sobre esta questão v. igualmente Osório, 2006, p. 49-50. 
os epítetos Ocelaecus e Ocelaeca, concernentes ao par divino Arentius e Arentia, derivados indígenas com o sufixo -aicus/-aica, particularmente difundido no âmbito do Ocidente hispânico, no qual se reconhece uma correspondência com o latim -ensis. Por isso, se sustentou, desde a primeira divulgação desta epígrafe (uma leitura inicialmente publicada no Diário de Notícias, transcrita em Rodrigues, 1982, p. 65-66) e reiteradamente (Leitão, 1981, p. 56-58; Albertos, 1985, p. 470; Garcia, 1991, p. 285, n. 11; Guerra, 1998, p. 197-198, 559-560; Prósper, 2002, p. 107, 109-110; Osório, 2006, p. 50) uma relação entre estes dois determinativos teonímicos e os Ocelenses documentados pelas fontes.

Adicionando estes contributos de diversa natureza, torna-se mais difícil compreender o cepticismo que alguns autores têm manifestado mais recentemente (Alarcão, 2005, p. 126-128; Carvalho, 2006, p. 228-232) a respeito da equação Lancienses Oppidani = Lancienses Ocelenses/Ocelenses Lancienses de Plínio. É certo que estes investigadores chegam a considerar que, com estes argumentos, "o problema parece resolvido" (Alarcão, 2005, p. 127) e que esta identidade "torna-se verosímil” (Carvalho, 2006, 229), mas acabam, na prática, por recusar essa possibilidade, mantendo a ideia de que os Oppidani ocupariam um território correspondente à bacia do Alto Erges. Jorge de Alarcão (2005, p. 127) estranha que em Plínio se use a expressão Ocelenses qui et Lancienses, em vez das esperadas Ocelenses qui et Oppidani ou Ocelenses qui et Lancienses Oppidani. Como se disse, o que os manuscritos registam é simplesmente Ocelenses Lancienses, expressão cuja novidade se encontraria apenas na ordem dos termos.

Pedro Carvalho (2006, p. 229-231) funda as suas objecções na ausência do qualificativo Oppidani no marco de Peroviseu, na lista de Ptolomeu e, acima de tudo, porque deste modo "se formaria um território sem a necessária homogeneidade" (2006, p. 230). Em primeiro lugar, não compreendo, sinceramente, o que se entende por "homogeneidade" do território, como se determina ou se aplica essa noção, sobretudo na região em análise, na definição dos amplos territórios destas entidades políticas; além disso, está absolutamente fora de causa aceitar que uma das áreas a que alude, a mais oriental, integre este município. O seu âmbito geográfico poderia ser, aproximadamente, o que propõe para os Ocelenses (Carvalho, 2006, Mapa 4; para um dos possíveis traçados alternativos aos seus limites meridionais v. Curado, 2004, p. 81 , n. 25 ; no prelo), afinal um dos seus nomes. 
Sobre a questão da terminologia utilizada na epígrafe de Peroviseu e em Ptolomeu não vejo qualquer dificuldade. O terminus não contém nenhuma incongruência, porque separa realmente Igaeditani e Lancienses. Creio que, aceites todos os outros argumentos, não é necessário comprovar que se trata aqui dos Oppidani, nem, para resolver a questão essencial, me parece relevante encontrar uma explicação inabalável para a ausência deste último elemento. Julgo, ao invés, completamente inútil especular sobre esta última circunstância, que não acrescenta nem retira nada ao problema de base, a não ser que se pretenda defender a existência de uma realidade apenas com esse nome (Lancienses) e distinta de todas as outras, o que me parece insustentável.

Por fim, basta conhecer a forma de compilação de dados e o seu processo de transmissão para resolver as eventuais dificuldades postas pelo texto de Ptolomeu. Na generalidade, este ou outros geógrafos clássicos não estavam em condições de saber que, neste finis terrarum desconhecido da maioria, o topónimo pré-romano de Ocelum corresponderia ao nome latino oficial de Lancia Oppidana. Por isso, este autor ou as suas fontes juntaram os dois, eventualmente colhidos em auctoritates diferenciadas, num mesmo elenco das cidades vetónicas.

Em suma, perante os últimos desenvolvimentos que esta questão sofreu, considero que há argumentos sólidos para sustentar a existência, na Lusitânia, de apenas dois Lancienses, os Transcudani e os Oppidani, sendo estes últimos equivalentes aos Ocelenses.

As questões que se prendem com a sede destas entidades e com os seus territórios, aspecto essencial desta investigação, motivaram importantes contributos recentes e podem, na minha perspectiva, receber um novo impulso com a análise da documentação actual. Para o estudo destes populi tem-se contado, acima de tudo, com os dados das fontes escritas referidas, as quais contribuem com informações de extrema importância para a localização destas entidades. Em primeiro lugar destaca-se a recorrentemente citada inscrição da ponte de Alcântara, inestimável ajuda nesta delicada questão. A relevância que este documento assume na discussão em torno da atribuição de um território às entidades nele mencionadas decorre essencialmente do facto de a sua ordenação obedecer a critérios geográficos. A disposição que cabe a cada uma delas no elenco depende claramente do lugar que ocupa no sistema viário desta parte da Lusitânia, em concreto nos seus dois principais percursos (v. especialmente Carvalho, 2006, p. 270; Osório, 2006, p. 47). 
O primeiro segmento de via parte dos territórios dos Igaeditani, limitado pelo curso Tejo, e termina certamente no vale do Douro, com a referência aos Colarni. O segundo, que constitui uma variante mais oriental do anterior, abarca um traçado que se inicia com os Lancienses Transcudani e finaliza nos Arabrigenses, podendo eventualmente confluir no primeiro traçado. Por fim, referem-se dois ramais de menor importância que asseguram ligação a outras regiões, a respeito dos quais não há ainda uma opinião unânime. Na minha perspectiva, um desses percursos atravessa o Douro num ponto mais interior, por altura do território dos Banienses e deveria ter continuidade para norte; o outro estabelece uma ligação entre a primeira de todas as vias referidas e o grande eixo litoral, que vai de Olisipo a Bracara, servindo os Paesuri (Guerra, 1998, p. 575-578).

Este esquema interpretativo parece-me totalmente coerente com os dados disponibilizados até ao momento por outras fontes e é igualmente compatível com elementos conhecidos a respeito de entidades ausentes da lista referida, explicando-se perfeitamente a sua exclusão deste elenco. Considero, por isso, que devem aceitar-se todas as implicações que daqui decorrem. Não se compreende, em especial, que Jorge de Alarcão continue a preferir uma localização meridional dos Tapori, na região de Castelo Branco ${ }^{2}$ (1990a, p. 371 em alternativa a uma situação "nas vertentes orientais das serras da Estrela e da Gardunha"; 1990b, p. 29; 1998, p. 147; 2001, p. 299 e 303 e, mais recentemente, em 2005, p. 122-123; juntamente com Imperial em 1996, p. 42), quando estes se encontram entre os Lancienses Oppidani, cuja situação a norte dos Igaeditani se encontra bem apoiada na documentação (v. infra), e os Interannienses, por ele próprio colocados, com sólidos argumentos (Alarcão, 1989a, p. 305-306; 1989, esp. p. 16-19), na região de Viseu, e com sede nesta cidade (contra Mantas, 2002, p. 232 e 234). Por essa razão, sustento, como o fiz anteriormente (Guerra, 1998, p. 628-630), que a hipótese mais viável foi já postulada por F. Patrício Curado (1988-1994, p. 215; 2004, p. 78, nota 5) e J. L. Inês Vaz (1997, p. 321), ao apontarem para a sua localização a vertente norte da Serra da Estrela, relacionando este NE com as ruínas da cidade romana da Bobadela, Oliveira do Hospital.

2 Esta opinião é partilhada por vários autores, nomeadamente por Ana Paula Ferreira (2000, p. 160-163) e tomada com algumas reservas por Pedro Carvalho (2006, p. 270-274). 
Como se verá, na análise dos problemas relativos aos Lancienses assume, por fim, um especial revelo o estudo da viação romana nesta região.

\section{Os Lancienses Transcudani}

A questão do território desta entidade ${ }^{3}$ esteve desde sempre vinculada à interpretação do termo Transcudani e a solução a dar a esta questão deverá contemplar o seu esclarecimento. De uma forma geral a tradição historiográfica aceitou quase unanimemente que este determinativo dos Lancienses tinha que ver com o antigo nome do rio Côa, cuja forma se estabelecia, com base nesta referência, como *Cuda. Uma das mais antigas propostas neste sentido colhe-se nas Antiguidades da Lusitânia, em que André de Resende afirma: Cudam Lusitani Coam vocant. Cudam autem vocari, ex inscriptione pontis Alcantarae, ubi Transcudani notati sunt animadverti (Resende, 1593, p. 78-79). Na mesma linha se orienta a interpretação José Leite de Vasconcellos (1905, p. 33-34; $1959^{3}$, p. 302) que se encontra bastante generalizada.

Contra esta interpretação tradicional se manifestou F. Patrício Curado (1988-94, p. 216, 224) ${ }^{4}$, baseando-se no facto de o hidrónimo correspondente em alguns documentos medievais ser Cola e nunca Cuda e na circunstância de o rio não ter características de marca divisória nessa região. Sustenta, por isso, que seria a Serra da Malcata e os prolongamentos da Serra da Estrela que constituiriam o separador territorial entre Oppidani, a sul, e Transcudani, ocupando estes a parte oriental do distrito da Guarda.

Mesmo sem ser confrontado com esta interpretação, José Pedro Machado tinha já proporcionado elementos que configuram uma resposta a esta objecção, ao considerar que os registos medievos a que se aludiu correspondiam a uma falsa reconstituição etimológica, muito frequente neste período, decorrente da busca de uma forma latina antecessora de um topónimo coevo (contra Alarcão, 2001, p. 297). Constata, nomeadamente, que a atestação mais antiga refere já o flumen Coa

3 Um elenco recente das diferentes propostas de localização dos Lancienses Transcudani e sua avaliação global pode encontrar-se em Osório, 2006, p. 84-86.

4 A sua proposta retoma-se em Alarcão, 2001, p. 297 e Osório, 2006, p. 96, eliminando-se, neste último caso, o carácter hipotético das considerações de F. P. Curado. 
(1145), registando-se Cola em documentos de 1182 (Machado, 1984, p. 427). A capacidade probatória destes registos medievos e a natureza pré-romana destas formas é, por isso, bastante limitada ou mesmo nula. Ao contrário, a viabilidade da interpretação tradicional está absolutamente fora de causa do ponto de vista histórico e linguístico e adquire igualmente consistência à luz dos dados arqueológicos e epigráficos.

No processo de identificação do território de todas estas entidades desempenha um papel importante - e não apenas pelas razões aduzidas supra - o traçado viário da região. Era natural que os centros administrativos criados no âmbito da reorganização do território não ficassem à margem das vias que foram sendo lançadas. Parece uma circunstância que não necessita de comprovação que os centros políticos criados no âmbito da demarcação territorial que se afirma com Augusto - os oppida stipendiaria plinianos - foram preferencialmente situados nesses eixos de comunicação e deles se contaram, a partir de determinado momento, as distâncias assinaladas nos marcos miliários. Por essa razão, estes elementos têm dado consistência a algumas identificações, sendo o caso de Viseu um dos exemplos mais notórios.

Como se reconhece habitualmente e já se assinalou acima, existiam (pelo menos) dois percursos que ligavam a civitas Igaeditanorum ao vale do Douro. O mais oriental percorria sucessivamente os territórios desta entidade, o dos Lancienses Transcudani e dos Araui, cuja sede se identifica seguramente com Marialva, Meda (Alarcão, 1973, p. 99-100; Tovar, 1976, p. 254; Guerra, 1998, p. 290-291), continuando pelo dos Medubrigenses e dos Arabrigenses, tal como decorre da inscrição da ponte de Alcântara. Com base nestes dados, parece claro que a este traçado devem pertencer dois marcos miliários que se registaram em S. Estevão e Alagoas, localidades integradas no concelho do Sabugal (Alarcão, 1988b, II, p. 68, respectivamente 4/345 e 4/344). Neste último se contariam supostamente IV milhas, o que serviu de base a uma proposta segundo a qual a vila do Sabugal corresponderia ao antigo estabelecimento de um centro político dessa região, em concreto a sede dos Transcudani. O principal óbice reside no facto de o suposto numeral resultar de uma deficiente leitura da epígrafe ${ }^{5}$, mas, para além disso, também se levanta a questão da inexistência nesse lugar de vestígios arqueológicos compatíveis com o estatuto municipal, limitados

5 Agradeço a Fernando Curado esta informação que integra um trabalho sobre a viação desta área, de próxima publicação. 
a uma "necrópole", uma lápide funerária e uma inscrição votiva a Arentia Equotulaicensis.

Quanto ao marco de S. Estevão, atribuído a Tácito, surpreende a leitura do numeral IIIX, que deveria representar o número de milhas que separavam esse ponto, de um caput viarum. Faria sentido, na minha perspectiva, que aí se marcasse a distância que separava o lugar do achado do sítio do Mileu, Guarda, no qual os Lancienses Transcudani tinham inequivocamente a sua sede 6 , como se tornou mais claro com a investigação recente de Pedro Carvalho (2005, p. 160-161; 2006, p. 723-725), apesar das hesitações que ele próprio manifesta a este respeito.

A primeira intervenção de vulto no local, no entanto, remonta já a 1951, ano em que Bairrão Oleiro dirigiu trabalhos que contaram com a colaboração de Luciano Cardoso e Adriano Vasco Rodrigues. Embora a informação disponível sobre estas acções mais antigas seja escassa, entre as descobertas mais relevantes encontram-se um edifício termal romano (Rodrigues, 1962, p. 8; Pereira, 2005, p. 231) e uma epígrafe funerária dedicada a Fronto Lauri f(ilius) Taporus (Rodrigues, 1958, p. 98).

Estes vestígios de identificação mais antiga e outros elementos de cronologia anterior, aparecidos tanto neste sítio como na própria cidade actual, entre eles o que se considerou a cabeça de um "guerreiro lusitano", consolidaram a ideia entre alguns investigadores locais de que o moderno aglomerado urbano se deveria encontrar aproximadamente no lugar da antiga Lancia Oppidana (Almeida, 1945, p. 48-71; Rodrigues, 1977, p. 34).

Quanto aos achados do Mileu, a interpretação que a investigação arqueológica consagrou orientou-se em sentido muito distinto, tendo prevalecido a ideia de que, na realidade, estes corresponderiam a uma villa, sem dúvida de certa importância, mas afastando-se a hipótese, por falta de elementos taxativos, de qualquer um desses pontos corresponder a uma cidade (Alarcão 1988b, II, p. 63-64 4/268; 4/269).

No ano de 2000, sob a responsabilidade de Vítor Pereira, retomaram-se os trabalhos no sítio arqueológico de Póvoa do Mileu, hoje já integrado no perímetro urbano da cidade da Guarda, que se prolongaram por 2001 e 2002 (Pereira, 2005). As intervenções recentes, para

6 Creio, por essa razão e pela estranheza da sigla numeral IIIX, que teria mais cabimento a sequência XIIX, viável do ponto de vista geográfico. 
além de confirmarem a natureza das construções já anteriormente identificadas, sublinharam o considerável poder económico desse habitat que deverá ter tido uma ocupação bastante prolongada, tendo-se iniciado eventualmente em período pré-romano e mantendo-se para além do séc. IV d. C. O principal edifício estudado sofreria uma remodelação entre os finais de séc. II e inícios do séc. III d. C., sem que isso representasse uma quebra da continuidade e da relevância do lugar (Pereira, 2005 , p. 242).

O mobiliário identificado atesta uma boa inserção do local nos circuitos comerciais, a ponto de se considerar a hipótese de ter funcionado como uma plataforma distribuidora de importações de sigillata ou de centro mineiro de certa importância. A interpretação dos dados arqueológicos obtidos nestas campanhas recentes teve o mérito de chamar a atenção para a necessidade de se reconsiderar a natureza do sítio. E, embora o responsável por estes trabalhos não tivesse retirado a última ilação que parece decorrer da análise das estruturas e dos espólios identificados, deixou um largo caminho aberto a uma nova interpretação, chegando mesmo a afirmar que "poderia corresponder a um centro político e administrativo de uma rede de povoamento" em que se incluíam mais três importantes habitats do território circundante (Pereira, 2005, p. 241).

Manuel Sabino Perestrelo (2003, p. 134) tinha já conferido uma nova interpretação ao conjunto dos restos materiais subsistentes nesse sítio arqueológico, ao considerar, contra a perspectiva mais difundida, que esses vestígios eram substancialmente mais importantes que quaisquer outros da região e deveriam corresponder a um núcleo populacional de consideráveis dimensões, opinião sustentada igualmente por Marcos Osório (2006, p. 87).

Retomando esta ideia no texto das actas da reunião científica em que os resultados dos recentes trabalhos no Mileu se apresentaram, Pedro Carvalho, ao ponderar alguns problemas concretos de identificação de civitates da Beira Interior, sugeriu que esse local constituía a mais coerente das hipóteses de localização para a sede dos Lancienses Transcudani (Carvalho, 2005, p. 160; 2006: 724-725), preterindo as alternativas de uma identificação com a Quinta de S. Domingos (Sabugal) e com Moradios (Almeida). A atestação de estruturas que, pela sua qualidade e dimensão, pertenceriam seguramente a edifício público, a juntar ao facto de daí provir igualmente uma estátua loricata (Acuña, 1975, p. 48-50; Souza, 1990, p. 46), constituíam argumentos de peso 
a favor dessa possibilidade, embora admitisse não existirem os restos monumentais que caracterizam habitualmente os núcleos urbanos.

Não restam dúvidas que essa proposta revela bastante solidez, uma vez que radica num conjunto de argumentos de natureza arqueológica e epigráfica especialmente pertinentes quando tomados no seu conjunto. Como se referiu, as recentes publicações relativas aos trabalhos de campo realizados no sítio sublinharam de forma clara a grande quantidade e qualidade das cerâmicas finas identificadas, assumindo um carácter excepcional no contexto de idênticos vestígios de outros sítios da Beira Interior. Por outro lado, estes indícios compaginam-se bem com a monumentalidade de alguns edifícios, nomeadamente do conjunto termal, mais compreensível num contexto urbano, onde teria uma utilização pública, do que associado à natureza privada que teria no âmbito da pars urbana de uma villa.

Identificaram-se no local alguns elementos que, apesar de isolados e descontextualizados, se constituem como indicadores bastante claros sobre a natureza do lugar. De um lado encontra-se a já citada estátua loricata depositada no Museu Regional da Guarda, atribuída ao principado de Trajano (Acuña, 1975, p. 49-50; Souza, 1990, p. 46), cuja natureza excepcional no contexto das cidades da Lusitânia é incontestável. Para além de, no âmbito desta província, apenas se registarem idênticos vestígios em Mérida, parece evidente a normal ligação destas manifestações escultóricas com actos oficiais e públicos, promovidos em centros urbanos (Acuña, 1975, p. 130).

Por outro lado, uma epígrafe em que se refere um indivíduo, aparentemente um peregrinus identificado como Taporus, constitui mais um indício a este título muito significativo. A alusão à sua origem denuncia certamente a sua condição de forâneo, o que milita, ao mesmo tempo, a favor da importância administrativa do sítio, uma vez que estes centros políticos atraem com muito mais frequência os forasteiros.

Por fim, há uma elevada probabilidade de por aí passar um importante eixo viário (v. Est. I) que ligava a região dos Igaeditani ao vale do Douro, cruzando o âmbito dos Lancienses Transcudani, Aravi, Medubrigenses e Arabrigenses, circunstância que, não sendo por si só decisiva, assume, quando associada a todas as anteriormente referidas, um importante significado.

Em síntese, a equivalência que Pedro Carvalho sugere com algumas reservas pode considerar-se, à luz dos dados disponíveis, como bastante segura, devendo sobrepor-se às outras hipóteses já consideradas. 


\section{Os Lancienses Oppidani ou Ocelenses}

A identificação da sede dos Lancienses Transcudani com o sítio do Mileu vem, naturalmente, dar um importante contributo para clarificar a distribuição espacial das realidades administrativas romanas desta região e, nesse sentido, para a resolução de idêntico problema no âmbito dos seus vizinhos Oppidani.

Para a delimitação do território deste último oppidum stipendiarium (segundo a terminologia pliniana) contamos com dois elementos fundamentais, ambos coincidentes. O dado mais fiável e esclarecedor é constituído pela inscrição CIL II, 460, originária de Salvador (Penamacor), infelizmente perdida, mas cuja autenticidade e fiabilidade não se contesta actualmente. Trata-se de um terminus augustalis, datado pelo XXVIII poder tribunício de Augusto (entre 1 de Julho de 5 d. C. e o dia 30 de Junho do ano seguinte), o qual permite assegurar que o território dos Lancienses Oppidani se situava, neste ponto, a norte dos Igaeditani.

$\mathrm{O}$ verdadeiro alcance que esta informação deve adquirir encontra-se, todavia, dependente de um texto idêntico, registado num monumento atribuído a Peroviseu, Fundão (Foto 1), hoje conservado no Museu Municipal da sede de concelho (Vaz, 1977, p. 27-29). Vários editores deste último consideraram que a epígrafe corresponderia a um cópia do monumento original (Vaz, 1977, p. 28; Encarnação, 1979, p. 29; Le Roux, 1994, p. 487; Abascal, 1996, p. 73), o qual teria sido deturpado em alguns pontos, sem que esse facto tivesse alterado de forma substancial o seu primitivo conteúdo. Na linha de outros autores (Monteiro, 1974, p. 58-59; Alarcão e Imperial, 1996, p. 39-41; Alarcão, 1990a, p. 369, hesitando, no entanto, em 2005, p. 124; Carvalho, 2006, p. 218-219), expus já alguns argumentos que me levaram a considerá-lo um monumento original (Guerra, 1998, p. 174-175), cuja inscrição, bastante desgastada em alguns pontos, tivesse sido avivada em fase recente, com alguns equívocos pontuais ou alterações compreensíveis.

A esse momento corresponderia o texto acrescentado, aproveitando a pequena margem do campo epigráfico original, no qual se informa que ESTE LETIREIRO ESTAVA FEITO NO ANO, expressão que, na minha perspectiva, assegura que, na data que se indicaria de seguida, a inscrição latina já se encontrava realmente gravada nessa mesma pedra. Teria sido, de resto, o próprio autor do avivamento do

7 Onde se considera uma cópia do desaparecido marco de Salvador. 
texto latino que se encarregou de lhe apor esta informação adicional. É sintomático que este acrescento revele um lapicida que não domina as técnicas de paginação: não respeita os alinhamentos; não recorre a abreviatura mesmo quando seria recomendável; não calcule bem o espaço ocupado pela parte adicionada, a ponto de grafar apenas parcialmente a última letra e não lhe restar já espaço para a data. Neste, como em outros aspectos, o contraste da intervenção moderna com o resto do monumento é gritante.

A observação do bloco (Foto 1) parece ainda pôr em evidência a circunstância de se tratar de um suporte reutilizado, que se encontrava já afectado por duas fracturas. A maior, no topo, do lado esquerdo, atingiu a área de gravação primitiva; na base, do mesmo lado, uma outra condicionou o acrescento moderno, de modo que a palavra ESTE tem, manifestamente, de contornar esse espaço.

Para corroborar esta minha convicção sobre a cronologia antiga do monumento e da sua gravação podem invocar-se mais alguns argumentos que decorrem claramente, a meu ver, da análise do bloco inscrito. Em primeiro lugar, atendendo aos pormenores de natureza paleográfica, há que distinguir claramente duas "mãos": a do primitivo lapicida, com elevada qualidade técnica, que gravou as capitais com bastante rigor, obedecendo a um rigoroso trabalho de ordinatio, levado a cabo numa boa oficina regional, de onde resultam caracteres regulares e compatíveis com os modelos então vigentes; do outro, um ductus muito irregular (particularmente evidente no desenho dos SS) e que revela uma técnica incipiente. Por isso, sempre que se trata apenas de seguir os traços primitivamente delineados, a epígrafe ganha um cunho completamente diferente do que assume quando o artífice moderno não identifica as linhas originalmente marcadas, dando lugar a gravações claramente distantes dos modelos das oficinas romanas qualificadas. Esta discrepância de "mãos" torna-se especialmente evidente em dois casos: no comentário, em língua portuguesa, que adiciona ao texto latino e na sequência NOS da terceira linha.

Que o texto foi repassado em fase moderna, sobre uma gravação original, constitui um facto que decorre de alguns argumentos concretos: da circunstância de se ler CAESAP, na linha 1, com clara omissão de uma haste da letra $\mathrm{R}$, de que subsistem apenas ténues vestígios, a qual, por essa razão passou despercebida ao lapicida moderno; da operação com que se transforma a sequência PATER PATRIAE em PATER NOSTERIAE, apertando consideravelmente as letras NOS, que têm de 
preencher espaço onde antes se encontravam apenas os caracteres PA. Se o lapicida moderno estivesse simplesmente a copiar um texto, não teria por certo necessidade de reduzir de modo tão substancial o espaço a eles conferido. Este caso denota, por isso, a preocupação em encaixar uma sequência determinada num espaço já constituído, o que condicionava fortemente a gravação, circunstância que só poderia resultar de se trabalhar sobre uma inscrição já previamente inscrita e não sobre um campo epigráfico completamente livre. A existência de traços subjacentes revela-se também, na minha perspectiva, no desenho do $\mathrm{R}$ da sequência MART da segunda linha, onde se observa um prolongamento superior da barra oblíqua dessa letra.

Um outro traço da sua autenticidade revela-se numa evidente hierarquização das linhas desta epígrafe, constituindo-se três níveis distintos que se reflectem no módulo utilizado: uma altura superior na primeira linha; uma dimensão intermédia, na segunda; e um módulo reduzido, nas terceira e quarta linhas. Esta preocupação deve entender-se, na minha perspectiva, como uma característica mais própria de uma oficina romana do que do lapicida moderno, claramente menos destro no trabalho epigráfico.

Por fim, o próprio monumento em si corresponde integralmente ao modelo conhecido em outros casos idênticos, sendo igual aos que se identificaram em regiões vizinhas da Lusitânia setentrional e que resultaram de um plano de ordenamento territorial promovido pelo mesmo imperador. Tanto no que respeita ao próprio suporte como à própria gravação, são notórias as afinidades entre este monumento e os termini augustales salmantinos que se encontram em Ciudad Rodrigo (2), Ledesma, Traguntia (Hernández, 2001, p. 165-169, respectivamente nn. 191-192, 193 e 194) e os de Guardão, Tondela (AE, 1954, 88) e de Ul, Oliveira de Azeméis (AE, 1958, 10), todos eles tendo como suporte grandes blocos paralelepipédicos de granito de configuração idêntica, sem moldura, com medidas que se situam em torno de $1,50 \mathrm{~m} \times 0,50 \mathrm{~m}$. As afinidades estendem-se igualmente ao próprio texto e poderiam respeitar igualmente à cronologia da sua colocação, correspondente a uma data compreendida entre 1 de Julho de 4 d. C. e 30 de Junho de 6 d. C.

A este respeito, verifica-se uma tendência para assumir que na maioria dos termini referidos com explicitação do poder tribunício de Augusto se assinalaria a cifra XXVIII, razão pela qual esse numeral se reconstitui habitualmente no final da segunda linha do monumento 
de Ledesma (Hernández Guerra, 2001, p. 167-168, n. 193). Por esta razão cheguei a sugerir (Guerra, 1998, p. 167) que no marco de Peroviseu se lesse eventualmente a cifra XXIIX, que poderia ter sido alterada pelo lapicida responsável pela regravação, o que compaginaria todos estes textos epigráficos. Embora não seja de afastar essa possibilidade, todavia, tendo em conta que também na inscrição de Ul, e talvez na de Ledesma, se indicaria esta cifra, é preferível, por questões de princípio, apontar o marco de Peroviseu para o vigésimo sétimo poder de tribuno, admitindo assim que estes termini se distribuiriam por dois períodos anuais com início em 1 de Julho de 4 da nossa era. Pode, portanto, concluir-se que ambos monumentos respeitantes aos Lancienses se integram no mesmo processo de delimitação territorial levado a cabo durante um período bem determinado do principado de Augusto (Abascal, 1996, p. 73-74), mas não corresponderiam ao mesmo ano.

As bases para a localização dos Lancienses Oppidani assentam, em primeiro lugar, no marco de Salvador e nas breves considerações que a esse respeito teceu Jorge de Alarcão no seu Portugal romano, onde questiona a antiga hipótese de identificação da sua sede com Alfaiates (Sabugal), atribuída a Levy Maria Jordão (Alarcão, 1973, p. 98), mas que já remonta pelo menos aos meados do séc. XVIII (v. infra). As incertezas quanto à identidade destes com os Lancienses referidos no marco de Peroviseu, que suscitaram as interrogações de Inês Vaz há três décadas (Vaz, 1977, p. 28-29), foram mais tarde ampliadas por Jorge de Alarcão (1990a; 1990b; 1998a; 2001, 2005), em consequência da sua perspectiva de um quadro étnico desta área mais complexo, não tendo obtido até ao momento uma solução satisfatória ${ }^{8}$. Penso, todavia, que a configuração actual deste problema concreto permite unicamente uma saída.

Como procurei demonstrar acima, não há argumentos que sustentem a hipótese de existirem na Lusitânia três entidades administrativas distintas de Lancienses, uma vez que tudo aponta para a identidade de Oppidani e Ocelenses. Dessa duplicidade dá testemunho tanto o texto pliniano como a inscrição da ponte de Alcântara, embora cada uma destas fontes use terminologias distintas, o que, como se tem vindo a demonstrar, não resulta de modo nenhum incompatível. Mas é, natu-

8 Para um elenco das múltiplas propostas de identifição espacial desta entidade v., mais recentemente, Osório, 2006, p. 82-84. 
ralmente, a informação proporcionada por esta última epígrafe que pode dar um contributo mais consistente para a sua localização, tendo em conta as considerações e os argumentos expendidos supra a respeito das implicações geográficas da ordenação dos municipia no referido documento.

Toda a questão assenta, desde logo, na identificação do sistema viário da região, em especial no percurso seguido pela primeira ligação entre Augusta Emerita e Bracara Augusta, aquela que passava sucessivamente pelo território dos Igaeditani, Lancienses Oppidani, Tapori, Interannienses e Coilarni. Felizmente, este antiga via está documentada (Mantas, 1990, p. 226) por pontes, calçadas, mas, acima de tudo pelo aparecimento de um conjunto significativo de marcos miliários, decisivos na determinação do seu traçado. A sua distribuição ao longo do seu extenso curso, revela-se bastante irregular com particular concentração na área de atravessamento do Serra da Estrela e na região de Viseu. De qualquer modo, a conjugação dos diferentes níveis de informação proporciona um traçado genericamente bastante seguro, apesar de eventuais divergências pontuais entre investigadores a respeito de determinados pontos concretos (v. Est. I).

Depois de passar a ponte de Alcântara a via cruzava o rio Erges na ponte de Segura, inequivocamente de origem romana (sobre a questão dos elementos primitivos e seus restauros v. Gimeno, 1997), e dirigia-se à sede da civitas Igaeditanorum, passando pelas proximidades de Alcafozes, onde se registam dois fragmentos de miliário (Almeida, 1956, p. 157-158, nn. 24 e 25). Refere-se igualmente um suposto miliário da Idanha onde se identificaria a titulatura do imperador Augusto e que estaria na base das considerações sobre a antiguidade deste traçado viário (Alarcão e Etienne, 1976, p. 177; Mantas, 1990, p. 226). Fernando Curado ${ }^{9}$, em trabalho a publicar, chama a atenção para o facto de esse monumento, para além de não ser um marco miliário, provir na realidade de Alfaiates, Sabugal, tendo-lhe sido atribuída uma função e uma origem erróneas por Scarlat Lambrino (1956, p. 14-17), na base da qual se encontra este equívoco.

O percurso entre Idanha-a-Velha e a Torre de Centum Celas, por vezes tomada como uma mansio, é pontuado pelo menos por dois mar-

9 Agradeço profundamente a Fernando Curado estas pertinentes informações e toda a sua disponibilidade e empenho em discutir comigo os mais diversos problemas que este trabalho aborda. 
cos miliários que ajudam a configurar o seu traçado: o mais setentrional, registado nas proximidades de Salgueiro, foi dedicado a Valerius Licinianus Licinius Iunior (Vaz, 1977, p. 25-26, n. XIV); o outro, no qual se lê o texto Caes(ar)/Masumi/anus, provém do sítio próximo de Quintas da Torre (=Torre dos Namorados), ambas peças recolhidas por José Alves Monteiro e actualmente depositadas no Museu do Museu Arqueológico Municipal do Fundão.

A respeito deste sector do antigo caminho romano se apresentaram algumas propostas que consistiam, por via da regra, em apontar alguns pontos pelos quais deveria este passar. Jorge da Alarcão (1973, p. 95, seguido por Vaz, 1977, p. 26 e mapa) sugere um primeiro percurso por Idanha-a-Velha, Monsanto, Penamacor, Meimoa, Vale de Lobo, Caria, Belmonte, Ribeira do Colmeal. Mais tarde, reunindo simultaneamente a informação arqueológica e epigráfica, apresenta uma proposta mais viável, na qual alinha os sítios de Medelim, Bemposta, Ribeira das Taliscas, Pedrógão, Torre dos Namorados (onde se identificou um dos miliários referidos), Capinha, Caria, Ribeira do Colmeal (Alarcão, 1988a, p. 101).

Também Vasco Mantas enuncia primeiramente (1990, p. 226) uma sequência em que inclui Penamacor, Caria e Belmonte, e mais tarde (Mantas, 1993, p. 224) uma outra, composta pelas localidades de Capinha, Caria e Belmonte. Os ajustamentos, comuns aos dois autores, compreendem-se perfeitamente, pelo facto de Penamacor estar claramente fora do alinhamento geográfico, habitual num traçado viário romano, porque implicava uma mudança considerável da sua orientação.

Segundo as duas propostas mais recentes destes autores, bem como a de Pedro Carvalho nas suas circunstanciadas referências a este troço da via (Carvalho, 2006, p. 248-259), que consideram essencial o aparecimento do miliário proveniente de Torre dos Namorados, o sítio de Capinha seria um lugar de passagem, a partir do qual se tomava a direcção de norte até atingir a Torre de Centum Celas, passando por Caria. Embora a esta hipótese se apresentem algumas dificuldades, como a de enquadrar o achado idêntico de Salgueiro, demasiado a oriente do percurso proposto, é possível que o necessário estudo aprofundado desta questão não conduza a propostas substancialmente diferentes. Na verdade, os dados epigráficos são elucidativos e, ainda que a sua proveniência possa ser objecto de pequenos ajustamentos pontuais, não deverão alterar de forma significativa o quadro actual. 
Neste contexto, parece evidente que o troço em questão não passaria longe do lugar onde se identificou o terminus augustalis que se atribui habitualmente a Peroviseu ${ }^{10}$, com o qual se separavam os Lancienses dos Igaeditani. Se aceitarmos que a ordenação dos municipia respeita a sua disposição no sistema viário, então torna-se evidente que estes Lancienses não podem ser os Transcudani, referidos apenas na segunda sequência, consoante acima se explicou, mas terão de ser os mesmos Lancienses Oppidani referidos no terminus de Salvador, como de resto já havia sugerido J. M. Abascal (1996, p. 74).

Depois de ter deixado o território dos Igaeditani, entrava-se, ao ultrapassar a cumeada da serra de Peroviseu e seus prolongamentos, no âmbito dos Lancienses Oppidani (ou Ocelenses), o qual apenas se abandonaria depois de vencidas a linha de alturas da Serra da Estrela, entre Famalicão da Serra e Linhares, lugares pelos quais seguia este percurso cujo traçado foi parcialmente estudado, no troço entre Valhelhas e Taberna, de forma circunstanciada ${ }^{11}$ (Mantas, 1992, p. 170-173). Aí se iniciava, como decorre da interpretação que parece mais consistente (v. supra), o domínio dos Tapori, que partilhavam uma parte da fronteira norte da entidade em análise. Nesta perspectiva, os Oppidani confrontavam-se, a sul, com os Igaeditani ao longo de uma extensa linha que ia pelo menos desde a Serra de Penha Garcia até à Serra de Peroviseu $^{12}$. Por sua vez, os Lancienses Transcudani, cuja sede, como se viu, parece estar actualmente bem determinada, estendiam-se parcialmente para norte do território dos Oppidani. Para completar o quadro, falta referir que se encontra muito mais vagamente definida a fronteira ocidental deste "povo", que deveria corresponder igualmente ao limite oriental do ager Conimbrigensis. Recentemente Fernando Patrício

10 Sobre as incertezas a respeito da real proveniência desta epígrafe será em breve publicado um contributo de F. P. Curado (no prelo), cujo conhecimento antecipado cordialmente agradeço.

11 Sobre este troço, há que ter em conta as recentes observações de Fernando P. Curado (2002, p. 80). Não se deve esquecer uma recente proposta de Jorge de Alarcão (2002-2003, p. 168), retomada por Pedro Carvalho (2006, p. 268-270), que consideram uma alternativa viária à travessia da Serra da Estrela por Unhais da Serra, Loriga e Valezim.

12 Deve ter-se seriamente em conta uma proposta recente sobre o traçado desta linha divisória, divergente da convencional, apresentada por F. P. Curado (2004, p. 81 e no prelo), que postula a sua passagem pela Serra da Gardunha, Catrão, Quintas da Torre, Serras de Ferreira, de Santa Marta e do Ramiro. 
Curado (2004, p. 81) sugeriu que o topónimo Altar de Trivim (Alto do Trevim, Lousã) retirasse o seu nome do facto de corresponder a um trifinium que englobasse os territórios dos Lancienses Opidanos, dos Conimbrigenses e dos Taporos.

No seu âmbito se incluía, em conformidade, o importante conjunto de terras agrícolas constituído pelo alto vale do Zêzere e pelos seus tributários, a ribeira da Gaia e ribeira da Meimoa, este último apenas parcialmente englobado. É para esta área que ultimamente se têm apontado a localização de uma sede municipal, a meu ver com bons argumentos, embora só raramente se coloquem aí os Oppidani.

Algumas das anteriores formulações aproximam-se desta proposta, embora, na maioria dos casos, sejam mais imprecisas, apontando genericamente para uma localização setentrional em relação aos Igaeditani. Deste modo, Roldán (1968-69, p. 88) tinha considerado que o espaço ocupado por esta entidade se deveria situar a norte da Idanha-a-Velha "en plena Sierra de la Estrela".

Todavia, generalizou-se, a partir dos anos setenta, a ideia de que este município ocuparia uma região mais oriental, tomando como provável que o terminus de Salvador corresponderia a um dos limites poente da sua jurisdição (TIR J-29, p. 98, com principal bibliografia anterior). Esta proposta encontra-se expressa em Hurtado de San Antonio (1976, p. 610-612) que sugere concretamente uma distribuição pela envolvência de Valverde del Fresno. Numa linha de pensamento que parte do mesmo princípio, Jorge de Alarcão apontou igualmente para um espaço hoje administrativamente integrado, em grande parte, na Extremadura espanhola, com diversas formulações: a nordeste de Salvador, onde confrontavam com os Igaeditani e separando-se dos Transcudani (a ocidente e a norte daqueles) pelas Serras da Malcata e da Gata (Alarcão, 1988a, p. 37; 1988c, p. 45; 1990a, p. 369-370 e Mapa 11; 1990b, p. 29 e Fig. 1), cuja capital seria Penamacor (Alarcão, 1998a, p. 87); o seu limite ocidental poderia corresponder às terras de Penamacor e ao curso inferior do rio Erges, estendendo-se do rio Tejo ao monte Jálama (Alarcão, 2001, p. 306 e fig. 2 e 7) - Penamacor seria um simples vicus ou castellum (Alarcão, 2001, p. 299); na sua mais recente formulação, o seu território abarcava a bacia superior do rio Erges, enquadrado pelas serras de Penha Garcia, Malcata e Gata (Alarcão, 2005, p. 121).

Esta localização a oriente de Salvador é incompatível com a informação da ponte de Alcântara, caso a ordenação dos municípios obedeça 
a critérios geográficos e viários ${ }^{13}$, facto que é geralmente aceite pela investigação, entre eles por Jorge de Alarcão (mais recentemente, em 2005, p. 120). Se aos Lancienses Oppidani se seguem os Tapori, Interannienses e Coilarni, como decorre dessa epígrafe, então a explicação do traçado da via em causa resulta impossível sem recurso a anomalias. E, além disso, o quadro administrativo desta região sugerido por este mesmo autor torna-se ainda mais problemático por sustentar a existência autónoma, a norte dos Igaeditani, dos Lancienses Ocelenses. Justificar a ausência destes últimos na inscrição alcantarense por erro ou por uma criação posterior a Trajano (quando ela já seria referida por Plínio como entidade autónoma) parece constituir uma argumentação pouco consistente perante os fortes indícios que pesam na direcção contrária e que acima se expuseram.

Como assinala Pedro Carvalho, as diferentes propostas de Jorge de Alarcão "levantam algumas reservas": por que razão estas entidades políticas se apresentam por aquela ordem (Carvalho, 2006, p. 270-275, onde se enuncia o problema levantado pela localização dos Tapori na zona de Castelo Branco e dos Lancienses Oppidani a oriente de Salvador), por que motivos estão estes presentes e se omitem outros (Carvalho, 2006, p. 273-27414); e, por fim, o que leva à omissão dos Lancienses Ocelenses, o que "à primeira vista não faz sentido" (Carvalho, 2006, p. 273-274)?

Por isso, esta nossa perspectiva, em alguns aspectos partilhada com outros investigadores, que coloca em sequência linear, ao longo de um bem conhecido traçado viário, os primeiros cinco municípios referidos na ponte da Alcântara me parece a mais lógica e a única que resolve, de forma simples, as questões associadas aos Lancienses.

\section{Centum Celas, a sede dos Oppidani}

A riqueza agrícola da área conhecida actualmente como a "Cova da Beira" é largamente sublinhada quando se trata de reflectir sobre

13 Veja-se, a este respeito, a interrogação já levantada por Pedro C. Carvalho (2005, p. 162).

14 A sua dúvida, lógica, consiste em saber porque razão se incluem aí os Lancienses Oppidani supostamente situados no Alto Vale do Erges e não aparecem também os Mirobrigenses e os Cobelci. 
a organização do território no período romano, em especial sobre os principais núcleos habitados desta região (Carvalho, 2003, p. 167-171; 173-182). Os seus extraordinários recursos levaram com frequência a que vários sítios se identificassem com uma das sedes municipais referidas na célebre epígrafe de Alcântara. De acordo com o que se disse, aí haveria que colocar os Lancienses Oppidani, aspecto para o qual os dados são bastante consistentes. Ao contrário, não foi possível determinar, com o mínimo de segurança, a que vestígios materiais haveria que associar o seu núcleo principal.

Como se referiu, uma das mais antigas propostas para a localização de uma cidade que poderia corresponder à Lancia Oppidana de Ptolomeu - manifestamente uma designação apropriada para a sede dos Lancienses Opidanos - foi atribuída a Levy Maria Jordão, que a apontava para o lugar de Alfaiates, hipótese que remonta a uma tradição anterior, uma vez que se regista já na conhecida obra do frade agostinho Henrique Flórez $\left(1786^{2}\right.$, p. 144). Esta suposição carece de fundamento (Alarcão, 1973, p. 98), mas a situação é idêntica a muitas outras hipóteses, igualmente inviáveis, que se foram colocando ao longo do tempo (Osório, 2006, p. 82-84).

Entre estas se encontra, por exemplo, a proposta de Mário Saa (1964, p. 228, 273), aqui apresentada como ilustração da ausência de fundamentação de uma proposta segundo a qual "os Lancienses Oppidanos, com inclusão dos Oceleses (Oqueleses), da cidade de Ocelum (Castelo Branco?) limitavam por oeste, noroeste e norte, o povo dos Igaeditanos. Sua capital, Lancia Oppidana, achava-se no alcarial romano da Serra d'Opa, ao pé do Santuário da Senhora da Póvoa e não distante do castro de Sortelha Velha".

Tradicionalmente identifica-se com a Guarda e como tal aparece com frequência na literatura geográfica do séc. XIX (v. g. Butter, 1821, p. 33; Moroni, 1845, p. 97). Esta perspectiva é retomada por João de Almeida (1945) e dela ficaram muitos vestígios na tradição local, a que a investigação mais recente não deu muito crédito (Rodrigues, 1977, p. 19). O número das obras que recolhem alguns indícios, mais ao menos consistentes, de lugares que poderiam ter desempenhado um papel de centro político dos Oppidani é já considerável (Osório, 2006, p. 82-84), pelo que nos limitaremos sintetizar a informação mais relevante.

O facto de Leite de Vasconcellos (1934: 25-28) ter dado a conhecer uma inscrição, proveniente da aldeia de Teixoso (Covilhã) na qual se nomeava um $M$. Valerius Silo com a rara expressão de duunvir pri- 
mus deu azo a que esta localidade fosse tomada como uma sede municipal. Jorge de Alarcão (1990b, p. 29) preferiu ver nesta epígrafe um sinal de que nas suas proximidades se localizaria o centro político de um dos territórios assignados a uma das entidades já conhecidas. No entanto, hesita quanto ao oppidum concreto que se lhe deveria reportar: a sede dos Tapori (Alarcão, 1988a, p. 37-38, hipótese preterida por Ferreira, 2000, p. 160), dos Transcudani (Alarcão, 1993, p. 36-38) ou a dos Ocelenses (Alarcão e Imperial, 1996, p. 41; possibilidade preferida por Ferreira, 2000, p. 160-161; Fernandes, 2002, p. 14). Porém, J. L. Inês Vaz (1997, p. 320) considerou mais viável que o próprio lugar do achado correspondesse precisamente ao núcleo administrativo dos Oppidani.

A falta na aldeia do Teixoso de vestígios arqueológicos compatíveis com uma sede municipal, aliada à real possibilidade de a inscrição provir de outro lugar próximo, constituíram os principais argumentos contra a hipótese de relacionar o sítio com este núcleo urbano ou qualquer outro (Carvalho, 2003, p. 168-169). Por isso, ganharam alguma consistência as hipóteses de que esse monumento epigráfico fosse originário de algum dos lugares com mais relevantes restos materiais.

Terlamonte afirmou-se em determinada altura como uma das candidatas a ser o lugar de origem dessa epígrafe, o que equivaleria a dizer, uma "capital" de civitas. Essa qualidade foi-lhe atribuída por Helena Frade (1996, p. 887) e Jorge de Alarcão (1998, p. 146, 149), assignando-a aos Ocelenses. Os trabalhos arqueológicos, bem como os de prospecção geomagnética e de superfície aí realizados, acabaram, no entanto, por negar esta possibilidade (Silva e Carvalho, 2004, p. 103-104; Carvalho, 2003, p. 169), que viria a ser afastada por um dos seus proponentes (Alarcão, 2001, p. 297; 2005, p. 124).

Orjais, pela importância dos vestígios arqueológicos (Alarcão, 1988b: 68) e epigráficos do sítio e das suas proximidades e ainda pelas evidentes potencialidades agrícolas da área em que se situa foi apontada, por várias vezes, como sede municipal. Não surpreende, assim, a sua associação com os Oppidani, proposta que foi sustentada recentemente por Fernando Patrício Curado (2004, p. 76, 80), que a considerou uma localização "quase segura". Pedro Carvalho (2003), na sequência da escavação do templo romano de Nossa Senhora das Cabeças, analisou igualmente esta mesma questão e, com base em dados de natureza diversa, concluiu que essa área revela uma particular concentração de elementos que denunciam "ambientes culturais e contextos sócio-económicos particularmente privilegiados" (Carvalho, 2003, p. 170). Ora 
este local seria o único, "com a ressalva, obviamente, de Centum Cellas" (Carvalho, 2003, p. 170, note 45), em condições de preencher esses requisitos. Todavia, quando se trata de decidir sobre a entidade a que respeitaria, opta pelos Lancienses Ocelenses, que considera distintos dos Oppidani (Carvalho, 2003, p. 174 e Est. I).

Dado que, na sequência de uma determinada interpretação dos dados literários, alguns autores apontaram para os Lancienses Oppidani um território situado a sul da Serra da Gata, formularam-se algumas hipóteses de localização da sua sede nesta região. De uma maneira geral, os defensores desta perspectiva remeteram-na para um sítio incerto de território espanhol (Hurtado, 1976, 610-612; 1990a, p. 37; 1990b, p. 29; TIR J-29, p. 98). Todavia, Penamacor foi referenciada, em diversas ocasiões, como uma das hipóteses concretas de correspondência da "capital” dos Oppidani (Alarcão e Imperial, 1996, p. 41; Alarcão, 1998, p. 146-147; 2001, p. 299), ainda que por vezes com algumas reservas. Uma das objecções, levantada por Jorge de Alarcão, decorreria de uma hipótese, sustentada numa problemática interpretação linguística do moderno topónimo, segundo a qual este poderia remontar a uma forma *Macur ou *Macurium, pelo que não poderia corresponder a Lancia Oppidana (Alarcão, 2001, p. 299). Num dos seus artigos mais recentes, o mesmo autor (Alarcão, 2005, p. 122), afastando as evidentes dificuldades desta hipótese e pressupondo que o marco de Salvador representaria o limite ocidental dos Oppidani, a quem atribui a bacia hidrográfica do Erges, interroga-se se Salvaleón ou Valdelospozos (esta última proposta tinha já sido avançada em Osório, 2000, p. 63 e 70; Osório, 2006, p. 87), os sítios arqueológicos mais conhecidos desta área extremenha, não poderiam corresponder ao seu núcleo principal.

Constata-se, enfim, que as últimas décadas foram pródigas em propostas de identificação das entidades desta área e dos respectivos núcleos urbanos. Não deixa mesmo de surpreender a facilidade e a frequência com que se avançam hipóteses ou, ao contrário, se recusam determinadas correspondências, sem que estas assentem, na maioria dos casos, em argumentação minimamente consistente.

Uma parte da argumentação que sustenta a nova proposta foi já apresentada e orienta-se fundamentalmente para a comprovação de que a área hoje grosso modo correspondente à Cova da Beira teria sido território dos Lancienses Oppidani. Trata-se agora de aduzir argumentos que confirmem a identidade da sua sede com os vestígios correspon- 
dentes à Torre de Centum Cellas (Colmeal da Torre, Belmonte) e a toda a sua envolvência.

O dado essencial reside no facto de aí existirem os vestígios, não de uma mansio, ou pretório, mas de um forum, conclusão que deve, na minha perspectiva, resultar da análise das estruturas postas a descoberto pela laboriosa investigação arqueológica de Helena Frade (1993-94, 1996, 2002, 2005).

Recorde-se que a interpretação dada aos vestígios monumentais mais evidentes, lembrando uma torre, aspecto que se fixou na toponímia, variou consideravelmente ao longo do tempo, especialmente antes de aí se ter realizado qualquer investigação sistemática de campo. Sem ser exaustivo, consideraram-se, especificamente, as hipóteses de o conjunto edificado corresponder a atalaia, uma prisão (Almeida, 1945, p. 408), um pretório de um acampamento militar (Rodrigues, 1962), um santuário ${ }^{15}$ (Correia, 1928, p. 243), uma mansio viária (Belo, 1964, p. $140 ; 1966$, p. 25-35; 1970, p. 46-49) e uma villa (Alarcão, 1988a, p. $118 ; 1988$ b, p. 65) hipótese que precedeu e pode em certa medida ter condicionado a interpretação dos resultados da intervenção de Helena Frade no local.

A possibilidade de corresponder a uma mansio, decorre naturalmente da circunstância de junto a esta construção passar uma via romana, como o sublinham os diversos marcos miliários que permitem definir, nessa área, um percurso bastante seguro. Apesar de parecer, por essa razão, uma sugestiva hipótese, nunca se fez uma verdadeira comparação entre os vestígios subsistentes e qualquer outra estrutura que pudesse ser classificada como tal. Por outro lado, esta sugestão não teve na devida conta o enquadramento do monumento, associado a vestígios dispersos por uma ampla área, de que essa estrutura representava apenas uma pequena parte. Tornou-se ainda mais claro, depois das escavações aí conduzidas por Helena Frade, que esta proposta tradicional não é viável, sobretudo depois de se considerarem as excepcionais dimensões do complexo construtivo, a qualidade da sua feitura, bem como a ampla área ocupada por todo o habitat envolvente.

15 Na realidade Vergílio Correia é bastante cauteloso, dizendo apenas que "atrevemo-nos a aproximar" esta torre de um edifício idêntico de Plasência, que Melida considera um "santuário isolado". 
A investigação conduzida por Helena Frade pôs em evidência um conjunto de construções que, à excepção do edifício respeitante à própria "torre", se apresenta quase sempre mal conservado, subsistindo em muitos casos apenas os seus alicerces e, não raro, unicamente os negativos correspondentes, marcados na rocha de base. De qualquer modo, a ampla informação já disponibilizada (Frade, 1993-94, 1996, 2002, 2005), juntamente com algumas observações feitas no local, constituem uma base suficiente para a sua interpretação.

Analisando globalmente a planta publicada (Est. II), constata-se que a sua estrutura recorda um conjunto tipicamente forense, com as suas componentes características essenciais.

Em primeiro lugar pela qualidade de construção e monumentalidade do edificado, aspecto seguramente associado à de criação e desenvolvimento de centros políticos que materializavam um ordenamento jurídico e administrativo de que nos dá conta Plínio. Não será despropositado pensar, por isso, que estruturas deste tipo devem corresponder a um dos 45 oppida a que se alude num passo de particular relevo para o estudo do problema vertente. Estas realidades administrativas tinham seguramente, como materialização de um ordenamento jurídico, um centro que, neste território longínquo, só com o tempo foi ganhando um cunho urbano. Num período ainda difícil de determinar, dada a escassez de dados para o Ocidente hispânico e a compreensível diversidade de situações, estas vieram, com maior ou menor rapidez, a ser dotadas das componentes essenciais que faziam de cada uma delas um exemplo do poder unificador do domínio romano.

Obedecendo a cânones bem conhecidos - por vezes identificados com os que se coligem na obra de Vitrúvio, mas que são mais genericamente modelos da própria arquitectura clássica em geral - os arquitectos destes conjuntos edificados gizavam adaptações a casos concretos, dando origem a uma diversidade enorme de aplicações, mas em cuja raiz se encontram esses princípios, normalmente fáceis de identificar. Não admira, pois, que Helena Frade reconheça neste complexo as marcas dos "preceitos vitruvianos", ainda que orientados para uma interpretação determinada (Frade, 2002, p. 115; 2005, p. 252), diferente da que aqui se propõe.

Entre estas características essenciais se encontra, naturalmente, a monumentalidade, tão evidente que a própria responsável pelos extensos trabalhos arqueológicos e autora de importantes publicações sobre os mesmos a assinalou de forma muito sugestiva, chegando mesmo a 
afirmar que "o tipo de silharia utilizada, as suas dimensões, as técnicas do talhe da pedra e o modo como foram trabalhados os encaixes $\underline{\text { são }}$ pouco habituais em villae, parecendo mais próprias de fortalezas ou grandes edifícios públicos ${ }^{16 "}$ (Frade, 2002, p. 114; 2005, p. 252, sublinhados nossos).

Mais do que qualquer outra construção, estas estruturas respeitavam o princípio da ortogonalidade, da proporção e da simetria. Esta última norma geral, constitui, como muito bem assinala Helena Frade, um dos aspectos que marca de uma forma mais evidente o complexo construído, sublinhando o carácter único que esta particularidade teria entre as villae conhecidas no território português (Frade, 2002, p. 114; 2005 , p. 252). Essa característica excepcional deveria ser confrontada com a "descontinuidade arquitectónica dos diversos corpos e acrescentos" que marcaria todos os outros casos, segundo a análise de Jorge de Alarcão (1988a e 1988b) e de J.-G. Gorges (1979), mas que aqui se não verificaria.

Apesar de a sua avaliação se tornar difícil nos momentos mais tardios, este traço de simetria e proporção manter-se-ia ao longo das suas diferentes fases, entre os séculos I e IV d. C. (Frade, 2002, p. 113; 2005, p. 252) circunstância que pode considerar-se algo rara. Para se configurar uma situação normal, parece-me mais aceitável que uma boa parte das estruturas corresponda a uma obra realizada de acordo com um único plano, executado em continuidade. Esse facto torna-se evidente nas construções que definem o edifício forense e todos os seus monumentos e essa é, na realidade, a razão principal e a justificação da natureza evidentemente proporcionada e simétrica de todo o conjunto. Nos seus traços mais gerais, este deve, na minha perspectiva, ser analisado como um todo e não como uma justaposição, ao longo do tempo, de construções atribuíveis a diferentes períodos.

16 A natureza urbana deste lugar foi sustentada, ainda que sem argumentos concludentes, pelo general João de Almeida (1945, p. 407-408), tendo afirmado que junto à Torre de Centum Caeles (sic) "há vestígios de uma grande povoação", que corresponderia a uma "citânia lusitana", ao lado da qual os romanos fundaram uma nova cidade, "dotando-a dos edifícios e mais elementos concernentes a um importante centro político, industrial e comercial", sendo a torre o seu mais evidente vestígio. Misturando interpretação arqueológica com tradição popular, sugere que a dita estrutura se deveria interpretar como a uma prisão política, a " prisão das cem celas", na qual "com todos os visos de verdade /.../ teria estado o papa S. Cornélio”. 
Apesar de sublinhar a coerência e organização em torno de um pátio central deste conjunto edificado (Frade, 2002, p. 111), a responsável pelos trabalhos identifica três momentos distintos no seu processo construtivo.

O primeiro dataria de um período compreendido entre o reinado de Cláudio e o início do período neroniano, com base nos elementos recolhidos na camada 63 , fundação do muro 26 , que continha elementos que remeteriam para um momento anterior à primeira metade do séc. I da nossa era, em particular numismas de Tibério e Cláudio (Frade, 2002, p. 136). A segunda fase distinguir-se-ia pelo aparelho e identificar-se-ia pelos elementos cronológicos recolhidos na camada 43, cabouco do muro 57, em especial um fragmento de ânfora e um bordo de um recipiente de sigillata hispânica cláudio-neroniana, pelo que propõe o seu enquadramento num período não posterior ao último quartel do século I (Frade, 2002, p. 137-138). Por fim, refere uma grande remodelação nos séc. III e IV na parte norte da villa, que incluiria o aumento da construção através do completo fechamento do pátio, a alteração do esquema de circulação no edifício e a modificação de alguns pavimentos (Frade, 2002, p. 138-145). Neste caso a cronologia foi proporcionada por alguns fragmentos cerâmicos identificados por baixo de blocos graníticos in situ.

Nenhum dos elementos de natureza estratigráfica aduzidos por Helena Frade para a datação das diferentes fases é incompatível com a atribuição de todo o complexo construído ao mesmo momento, que seria necessariamente posterior a uma datação cláudio-neroniana, por força do conteúdo da camada 43. Pela coerência arquitectónica que o pórtico apresenta, não faz muito sentido, dentro dos princípios construtivos romanos, que tenha permanecido aberto pelo menos durante dois séculos e só então tenha sido fechado. Os argumentos de natureza estratigráfica invocados não contrariam esta possibilidade, mais coerente do ponto de vista urbanístico. As indicações cronológicas fornecidas para a 3 . $^{\text {a }}$ fase podem muito bem limitar-se a remodelações mais ou menos acentuadas da construção, mas não implicam necessariamente a natureza tardo-romano de um determinado sector do edificado.

Não se nega, portanto, que tudo o que subsiste foi edificado ao mesmo tempo, mas apenas que todo o plano do forum é concebido e executado num período relativamente curto, podendo ter sido modificado em diversas ocasiões. Algumas alterações a esse plano, sobretudo correspondentes a modificações do esquema de circulação no edifício, 
eventuais divisórias ou acrescentos facilmente se compreendem num contexto de uso prolongado de uma construção com esta natureza, modificações que parecem afectar em especial o ângulo sul do complexo. A uma fase completamente distinta respeitam, por exemplo, as construções que não obedecem ao alinhamento primitivo, isto é, as que se atribuem à $4 .^{\text {a }}$ fase (Frade, 2002, p. 140-149; 2005, p. 257 e 262). Estas pressupõem uma alteração substancial na ocupação daquele espaço e apontam necessariamente para um momento em que os edifícios a que se aludiu tinham perdido a sua função originária, encontrando-se abandonados.

O conjunto edificado possui dimensões que se aproximam de edifícios similares já conhecidos no Ocidente hispânico, aqueles que, naturalmente, lhe devem servir de paralelos. Originalmente com cerca de $64 \mathrm{~m}$, compara-se, por exemplo, com o forum augustano de Conimbriga e com o de Aeminium na sua extensão total, o primeiro com um pouco menos de $68 \mathrm{~m}$ e o segundo, de acordo com os cálculos de Pedro Carvalho (1998, p. 187), com 63 m (213 pés). As praças associadas a estes dois complexos públicos medem respectivamente, 38,10 m x 25,35 m (Alarcão e Etienne, 1977, p. 39) e 36,38 m x 23,36 m (Carvalho, 1998, p. 187), enquanto que a estrutura em análise apresenta as dimensões de $33,80 \mathrm{~m}$ x 22,30 m.

No entanto, o que marca de uma forma mais evidente a natureza do edificado é a sua própria organização e os seus constituintes, correspondentes de forma bastante clara ao que são os fora romanos ${ }^{17}$.

Em primeiro lugar, a praça rodeada por um pórtico, cuja estrutura corresponde, de modo inequívoco, aos modelos mais habituais neste tipo de construções. Não faltam, em alguns pontos, os plintos tão frequentes nestes lugares públicos, entre eles o que se situaria exactamente no eixo de toda a construção, no topo meridional da praça, que Helena Frade (2002, p. 134; 2005, p. 255 e 260) assinalou com a letra A. Trata-se certamente da base de um monumento que ocupa uma posição privilegiada, mas relativamente ao qual não dispomos de elementos minimamente consistentes que permitam determinar a sua função concreta.

O templo, situado no topo sudoeste do conjunto edificado, parece-me de identificação segura, tanto pela posição que ocupa no conjunto como pelo facto de estas estruturas apresentarem um plano relativamente característico. A análise da planta publicada por Helena Frade

17 Encontra-se em preparação um estudo especificamente dedicado ao forum de Centum Celas, pelo que apenas se abordam aqui algumas questões mais gerais. 
(1993-94, p. 107, Fig. 1; 2002, vol. II; 2005, p. 260-262) leva-me a considerar que a ele pertencem certamente os compartimentos definidos pelos números $\mathrm{IV}, \mathrm{V}$ e $\mathrm{XXV}$, que correspondem actualmente à própria "torre". Para além disso, o compartimento XVIII prolonga os alinhamentos destas estruturas, mas numa cota claramente superior, o qual poderá ligar-se a essa mesma construção. Mas o edifício sagrado deveria associar-se aos espaços representados pelos números I, II, III, VIII, VII e VI.

Vale a pena, para este efeito, registar as claras afinidades entre este edifício e o de Almofala, que se manifestam desde logo e de forma mais clara nas suas dimensões. Dada as incertezas a respeito do seu comprimento, é comparável a largura dos podia de ambos edifícios, que apresentam as medidas de $8,15 \mathrm{~m}$ (Frade, 1990, p. 97) e 8,52 m, esta última registada no de Centum Celas (Belo, 1970, p. 41), as duas, por sua vez, bastante próximas dos $9,20 \mathrm{~m}$ no da civitas Igaeditanorum (Frade, 1990 , p. 97, n. 8). A comparação do comprimento torna-se mais problemática, uma vez que o edifício em análise se prolongaria substancialmente para lá da torre, a qual apresenta, no estado actual, 11,34 m.

Tratando-se do forum de uma cidade, é natural que o núcleo até ao momento conhecido não se encontrasse isolado, mas fosse envolvido num amplo complexo habitacional. Já Pinho Leal (1873, p. 374) recolhera uma sugestiva informação de quem conhecera certamente o sítio em melhor estado de preservação, segundo a qual "em redor d'este edificio ha vestigios de outros, que demonstram ter aqui existido uma não pequena povoação". E é provavelmente essa importante tradição que se encontra na base da interpretação pioneira de João de Almeida (1945, p. 407-408) a que aludimos.

A evidência destes restos, todavia, chegou inevitavelmente até ao presente e dela dá igualmente conta Helena Frade (2002, 156-158; 2005 , p. 258) na sua bem documentada análise, apresentando uma interpretação para essa realidade arqueológica. Transmite, em primeiro lugar, uma informação segundo a qual a fotografia aérea revelaria, nas imediações, amplos indícios de outros edifícios, cujo alinhamento seria mais ou menos evidente. De facto, a documentação aerofotográfica mais antiga evidencia, em especial a noroeste da "torre", onde esses restos são particularmente visíveis, um conjunto de construções que denunciam um urbanismo ortogonal, muito provavelmente romano. Estes indícios encontram-se a várias centenas de metros do que consideramos o forum, sendo menos claras eventuais estruturas entre as duas reali- 
dades habitadas, devido à natureza do coberto vegetal e ao uso de solo dado ao espaço envolvente.

Não é de modo nenhum estranho que a ocupação continuasse igualmente em outras direcções, mas no sentido oposto abriu-se a estrada mais recente e desenvolveu-se ao longo dela a construção, consequência da expansão da aldeia, circunstância que deve ter obliterado os vestígios arqueológicos ainda subsistentes.

Torna-se hoje muito difícil, devida às vicissitudes que acompanharam o local ao longo do tempo, reconhecer muitos dos vestígios primitivos. Para além das condicionantes já referidas, estas "cidades mortas" constituem uma importante fonte de matéria-prima para a construção e, por isso, durante muitos séculos abasteceram de blocos já aparelhados os novos edifícios, por vezes em áreas bastante afastadas. Por outro lado, o exercício persistente da agricultura nestes solos de considerável valor produziu uma alteração substancial do subsolo, em especial em fase mais recente em que os potentes meios mecânicos utilizados para surribar estas terras, destinadas a pomar e vinhas (Frade, 2002, p. 156; 2005 , p. 258), conduziram a um apagamento quase total dos traços da ocupação antiga.

Apesar disso, o que o levantamento aéreo evidencia parece muito sugestivo a respeito da existência de uma mancha considerável de ocupação para além do que foi escavado, o que se compagina com a interpretação que se propõe para as estruturas já escavadas. De resto, a presença em toda a área de amplos vestígios de um mais amplo estabelecimento romano foi já reconhecido por Helena Frade. Todavia, na sua interpretação, o desenvolvimento de um habitat em torno à villa deveria corresponder a um vicus, cuja existência se atestaria não apenas nos vestígios arqueológicos, mas também numa epígrafe identificada nas escavações, que analisaremos mais abaixo. A situação insólita de uma villa gerar à sua volta um povoado de certa dimensão poderia, no entanto, encontrar alguns paralelos, nomeadamente o exemplo de Reinheim Bielsbruck (Frade, 2002, p. 156). Ao mesmo tempo, aduz argumentos a favor da constituição de núcleos habitacionais de consideráveis dimensões que poderiam inclusivamente ser propriedade de privados, invocando nomeadamente o bem conhecido caso recente de Colmeal, Figueira de Castelo Rodrigo (Frade, 2002, p. 156-157). Na generalidade, este vicus é considerado um espaço residencial construído pelo grande proprietário do fundus, a fim de nele albergar os seus serviçais que se dedicavam à actividade agrícola e à 
exploração mineira ${ }^{18}$, ou como a reutilização, com esta mesma finalidade, de um habitat anterior (Frade, 2002, p. 156-158; 2005, p. 258).

Por fim, há notícias de "um cemiterio bastante rico, em grande parte destruido" (Proença, 1910, p. 3) e de restos de um conjunto termal de que se teriam encontrado alguns arcos (Frade, 2002, p. 136) certamente pertencentes a um hipocausto, mas dos quais não há notícias mais circunstanciadas. Naturalmente, pela escassez de pormenores, estas notícias em nada contribuem para esclarecer a natureza do sítio, uma vez que se adequam a qualquer das explicações em confronto.

O carácter de sede municipal deste sítio reconhece-se, a meu ver, também na epigrafia, isto é, na única inscrição que podemos inequivocamente associar a este conjunto monumental. Trata-se de um pequeno monumento epigráfico (com 33×16,5x14,5 cm), encontrado juntamente com um grupo de 7 árulas anepígrafes, todas depositadas no mesmo compartimento, interpretado como o lararium da villa (Frade, 2002, p. $154 ; 2005$, p. 256). O seu texto, manifestamente problemático, foi dado a conhecer no catálogo da exposição Religiões da Lusitânia (p. 467-468), reproduzido-se nos mais recentes trabalhos sobre o sítio (Frade, 2002, p. 147; 2005, p. 256). Nele leu Carla Ferraz o seguinte: Pro SAN[---] / [--]et VICT[--] vici / L(ucius) Caeci[l(ius)-]ATOR/ [---]Veneri /BE[--- Min(?)]ervae / [---]LAENDOS / [--]I[---]TEC / [---] a(nimo) l(ibens) v(otum) s(olvit). Esta lição foi interpretada, apesar de algumas faltas de correspondência com o texto estabelecido, como uma dedicatória de Lúcio Cecílio a Victória e Minerva, pela incolumidade e triunfo do vicus.

Parecem manifestas, desde logo, as dificuldades em estabelecer o texto exacto desta inscrição que importaria certamente reanalisar com atenção. De qualquer modo, um dos aspectos que aparenta maior consistência é precisamente o início, onde deveria provavelmente encontrar-se uma expressão consagrada como pro salute, incolumitate et victoriae ou algo afim, como presume igualmente o autor desta proposta. Ora este tipo de sequência é praticamente exclusivo de dedi-

18 Achamos pouco provável que a exploração mineira, geralmente propriedade imperial e objecto de um complexo processo de concessão por parte do estado a entidades arrematadoras, pudesse constituir igualmente uma actividade de um proprietário agrícola, que, segundo esta interpretação, teria as minas dentro do seu domínio. 
catórias imperiais e maioritariamente pertencentes aos séc. II e III da nossa era ${ }^{19}$.

Embora possa revelar-se impossível, no estado actual de conservação do monumento, estabelecer qual o personagem ou personagens a que ele seria dedicado, é muito provável que se trate da figura do imperador, como ocorre em quase todas as epígrafes que registam sequências similares. Tal circunstância constituiria, pois, mais um argumento a favor da proposta que apresentamos, perfeitamente condizente com os dados já expostos.

Para além disso, não deixa de assumir um especial significado o facto de as sete árulas que acompanham este voto serem de mármore ou de calcário, matérias-primas que são estranhas à região. Esta circunstância deve, na minha perspectiva, interpretar-se como mais uma manifestação da natureza urbana do sítio, no qual os cidadãos e as entidades públicas preferiam, em especial no caso de actos relacionados com a vida cívica, os materiais mais nobres. Nestes casos, dava-se um especial destaque ao mármore, imitando os modelos de urbes mais importantes, como Mérida, onde os programas decorativos assentavam com frequência em obras que recorriam a este suporte. Desta forma, se marcava um contraste com alguns monumentos executados em suportes graníticos, certamente também presentes, mas a que se atribuía provavelmente menor dignidade.

Seria, por fim, interessante se dispuséssemos de um argumento baseado na contagem das distâncias indicadas nos miliários, ligados às poucas referências seguras ao número de milhas que se registam neste território e associados a uma via que incontestavelmente passava junto a Centum Celas. Geralmente reportam-se dois monumentos com estas características, um de Lameira, outro de Barrelas.

O miliário de Lameira foi encontrado não longe de Centum Celas e nele leu Ricardo Belo (1960, p. 41), para além do nome e titulatura do imperador Tácito (correspondente a finais 275 d. C.) a sequência II LO.

19 Manifesto as minhas reservas sobre a datação da epígrafe. Para além da precaridade dos fundamentos dessa cronologia, não é fácil aceitar que uma inscrição consagrada por um particular aos deuses pela protecção do vicus se mantivesse sempre no lararium familiar de uma villa ao longo de um extenso período que medeia entre os séc. I e IV d. C. As incertezas em diversos domínios, em particular no que concerne à própria leitura e interpretação do texto, explicam igualmente esta atitude de cepticismo. 
Ele próprio admitiu, inicialmente (Belo, 1960, p. 42), que o numeral poderia corresponder a uma contagem de milhas, mas estranhou o facto de ele vir, contra o que é habitual, antes do topónimo. Depois de considerar a possibilidade de se tratar do numeral seguido de letras, acabou por se decidir pela interpretação dessa sequência como PR[O]/CO[S] (Belo, 1960, p. 42-44). Todavia, ainda que com algumas dúvidas a respeito do numeral, Pedro Carvalho (2006, p. 258) considera a sua leitura inicial como correcta.

Como o achado se registou a cerca de $2,5 \mathrm{~km}$ da Torre também chamada de S. Cornélio, Pedro Carvalho admitiu que a distância registada nesta epígrafe viária se contaria a partir de um vicus ou castellum e este "só poderia ser o sítio de Centum Cellas" (Carvalho, 2006, p. 266), o que o leva a admitir a possibilidade de se ver no marco da Lameira uma referência à civitas dos Lancienses Ocelenses ou à dos Oppidani (Carvalho, 2006, p. 259, nota 27). No entanto, hesita sobre a explicação para esta medida, considerando igualmente a eventualidade de a contagem partir de um limite territorial originado na confluência do Zêzere com a ribeira da Gaia e acompanhando o leito deste último curso de água (Carvalho, 2006, p. 258-259), apesar de reconhecer (p. 258, nota 25) que as distâncias contadas a partir de lineae confinales "não são muito habituais". De acordo com esta interpretação, o documento ganharia um extraordinário relevo, não apenas porque se adequaria à distância indicada, como os dois caracteres corresponderiam perfeitamente às iniciais da civitas, Lancia Oppidana.

Em trabalho dedicado à viação desta área, em preparação, Fernando Curado analisa esta epígrafe, garantindo que no passo controverso se encontra, de facto, a sequência $\mathrm{PR}[\mathrm{O}--] / \mathrm{L} \mathrm{O}$, corroborando em parte observações anteriores (v. supra). A ser assim, a interpretação da parte terminal da inscrição deveria ser: $\operatorname{pr}[o c o(n) s(u l i)]$ / L(ancia) $O$ (ppidana). Deste modo, a seguir à titulatura não se registaria o numeral correspondente à distância, mas apenas o nome da localidade, tal como o tinha já desenvolvido Ricardo A. Belo. O facto de a interpretação desta abreviatura se adequar perfeitamente à proposta que, com base em outros argumentos se tem vindo a construir, faz com que este contributo se revele como mais uma achega de grande importância para a identificação deste lugar.

Também numa epígrafe viária reutilizada na igreja de Barrelas se registam as milhas, neste caso com o numeral IV, as quais poderiam hipoteticamente ser medidas a partir de Centum Celas, apesar de a peça 
ter sido identificada a uma distância muito superior, uma vez que se desconhece a proveniência exacta deste monumento. Trata-se, contudo, de uma mera possibilidade que não pode ter qualquer valor argumentativo no caso vertente.

Ainda que nem todos os dados sejam inequívocos, muitos elementos se compaginam bem com o facto de estarmos perante a sede dos Lancienses Oppidani, também chamados Ocelenses. Como se viu, a análise do território sob o ponto de vista administrativo e viário conduziu a que se apontasse para este sítio a sua localização. Mas também para tal dá um contributo não despiciendo o nome que a tradição consagrou para o local e que se recolhe nas fontes medievais. No essencial, de entre as diferentes variantes para o topónimo (Centum Cella, Centum Celli ou Centum Coli), domina uma versão Centumcellas e o que se considera a correspondente vernácula, que aquela forma pretende traduzir, Centocelas.

A primeira poderia configurar, como é habitual nos textos medievais, uma situação de adaptação de um termo local a uma forma latina, sofrendo este, por vezes, algumas alterações, entre elas a influência de um outro topónimo romano bem conhecido. Neste caso concreto, seria inevitável recordar a ampla divulgação da sequência toponímia Centum Cellae, várias vezes registada no contexto romano e amplamente divulgada. Tornou-se particularmente conhecido esse antigo topónimo correspondente à actual Civitavecchia (Itália).

$\mathrm{O}$ aspecto mais surpreendente reside no facto de o nome vernáculo conservado pelos textos medievais conter a sequência -ocellas, o que não pode resultar certamente de uma simples coincidência. Ainda que não seja fácil traçar uma história desta formação linguística e não me atreva a propor qualquer explicação para este nome por falta de um conjunto de atestações que permitam esclarecer o processo que levou à sua constituição, creio ser incontestável uma ligação com o antigo topónimo Ocellum, que se regista nos autores clássicos e que, ao mesmo tempo, se deduz da documentação epigráfica, nomeadamente dos epítetos teonímicos Ocelaecus e Ocelaeca ${ }^{20}$.

20 Estes epítetos referir-se-iam, tal como muitas vezes se sugeriu e acima se disse, não a um vicus eventualmente localizado nas imediações do Ferro, Covilhã (Alarcão e Imperial, 1996, p. 41), mas à própria entidade dos Ocelenses / Oppidani em cujo território esse lugar se inseria. 
Deste modo, parece conciliar-se de forma concludente a informação que se apura nos diferentes planos: no das fontes clássicas e medievais, da arqueologia e da epigrafia. Todos eles confluem no sentido de confirmar que os vestígios existentes na área da chamada "Torre de Centum Celas" correspondem inequivocamente à sede municipal que na inscrição da ponte de Alcântara se apresenta como dos Lancienses Oppidani, mas que também se chamavam Lancienses Ocelenses, ou mesmo Ocelenses Lancienses, de acordo com o texto de Plínio.

\section{REFERÊNCIAS:}

\section{Edições de textos clássicos:}

Caii Plinii Secundi historiae naturalis. Parma: Andrea Portilia, 1481.

C. Plinii Secundi historiae naturae historiarum libri XXXVII e castigationibus Hermolai Barbari. Venezia: B. Benali, 1497.

C. Plinii Secundi historiae naturalis libri XXXVII ab Alexandro Benedicto Ve. physico emendationes rediti. Venezia: J. \& B. Bubei, 1507.

Caii Plinii Secundi historiae mundi libri XXXVII ex postrema ad vetustos codices collatione cum adnotatione et indice. Basel: Froben, 1539.

C. Plinii Secundi historiae mundi libri XXXVII. Lyon: Antoine Vincent, 1553.

C. Plinii Secundi historiae mundi libri XXXVII. Ed. J. Dalechamps. Lyon: B. Honorat, 1587.

Cai Plini Secundi naturalis historiae libri XXXVII, recensuit et commentariis criticis indicibusque insturxit I. Silig. Hamburg/Gotha: F. \& A. Perthes.

Caii Plinii Secundi naturalis historiae: Band I, D. Detlefsen recensuit. Berlin: Weidmann, 1866.

Caii Plinii Secundi naturalis historia: Band I, recensuit K. F. Th. Mayhoff. Lipsiae: Teubner, 1906.

\section{Traduções:}

C. Plinius Secundus, the Historie of the World, translated into english by Philemon Holland, Doctor of Physick. London: Adam Islip, 1601.

Pline l'Ancien: Histoire naturelle, avec la tradution en français par M. É. Littré, vol. I. Paris: Dubochet, 1848.

Pliny the Elder: The natural history. Ed. J. Bostock; H. T. Riley. London: Taylor \& Francis, 1855.

\section{Outras obras:}

ACuÑa FernándeZ, P. (1975) - Esculturas militares romanas de España y Portugal, I. Esculturas thoracatas. Roma: CISC. 
AlarCão, J. de (1973) - Portugal Romano. Lisboa: Verbo.

Alarcão, J. de (1988a) - O domínio romano em Portugal. Mem Martins: Europa-América.

AlarCÃo, J. de (1988b) - Roman Portugal. 2 vol. Warminster: Aris \& Philips.

AlARCÃo, J. de (1988c) - "Os montes Hermínios e os lusitanos". Livro de homenagem a Orlando Ribeiro. Lisboa, p. 41-48.

AlARCÃo, J. de (1989a) - "Geografia política e religiosa da ciuitas de Viseu". Actas do I Colóquio Arqueológico de Viseu. Viseu, p. 305-314.

Alarcão, J. de (1989b) - A cidade romana de Viseu. Viseu.

AlarCão, J. de (1990a) - Portugal das origens à romanização. Lisboa: Ed. Estampa. AlARCÃo, J. de (1990b) - "Identificação das cidades da Lusitânia portuguesa e dos seus territórios". Les villes de Lusitanie. Hierarchies et territoires (Talence, le 8-9 décembre 1988). Paris, p. 21-34.

AlarCão, J. de (1993) - Arqueologia da Serra da Estrela. Manteigas: Parque Natural da Serra da Estrela.

AlARCÃO, J. de (1998) - "On the ciuitates mentioned in the inscription on the bridge at Alcântara”. Journal of Iberian Archaeology. Porto. 0, p. 143-157.

AlARCÃo, J. de (2001) - "Novas perspectivas sobre os Lusitanos (e outros mundos)". Revista Portuguesa de Arqueologia. Lisboa. 4/2, p. 293-349.

AlARCÃo, J. de (2005) - "Ainda sobre a localização dos povos referidos na ponte de Alcântara". Lusitanos e romanos no Nordeste da Lusitânia. Actas das 2. as Jornadas de Património da Beira Interior. Guarda: Centro de Estudos Ibéricos, p. 119-132. Alarcão, J. de; Etienne, R. (1976) - "Le Portugal à l'époque augustéenne". Symposium de ciudades augusteas. Zaragoza, p. 171-185.

AlarCÃo, J. de; EtIENnE, R. (1977) - Fouilles de Conimbriga, I. L'architécture. Paris: Diffusion De Boccard.

AlARCÃo, J. de; IMPERIAL, F. (1997) - "Sobre a localização dos Lancienses e Tapori". Miscelânea em homenagem ao Professor Bairrão Oleiro. Lisboa, p. 39-44.

AlmeIDA, F. de (1956) - Egitânia, história e arqueologia. Lisboa.

AlmeIDA, F. de (1962) - Restos de uma possível villa rustica nas proximidades da Guarda. Studium Generale. 9:1, p. 298-304.

AlmeIDA, J. de (1945) - Roteiro dos monumentos militares portugueses, Vol. I. Lisboa: Ed. do Autor.

BELo, A. R. (1960) - "Notas sobre cinco marcos miliários da via militar romana Mérida - Viseu - Braga, encontrados nas proximidades da Torre Centum Cellae de Belmonte". Revista de Guimarães. Guimarães. 70, p. 27-50.

BELo, A. R. (1964) - "Dois marcos miliários inéditos do troço Centum Cellae - Valhelhas da Via Militar Romana Mérida - Viseu - Braga”. Arqueologia e História. Lisboa. 11 ; p. 128-142.

Belo, A. R. (1966) - O problema da Torre Centum Cellae de Belmonte, mansio ou praetorium". Arqueologia e História. Lisboa. 12, p. 23-34.

Belo, A. R. (1970) - "Algumas palavras sobre a Torre Centum Cellae de Belmonte". Actas e memórias do I Congresso Nacional de Arqueologia (15 a 20 de Dezembro de 1958), vol. II. Lisboa: Instituto de Alta Cultura, p. 35-55. 
Bishoff, T.; Möller, J. F. (1821) - Vergleischendes Wörterbuch der alten, mittleren und neuen Geographie. Gotha: Becker.

Blanco Freijeiro, A. (1977) - El puente de Alcántara en su contexto histórico. Madrid. ButLer, S. (1821) - Geographia Classica or the application of the Antient Geography to the Classics. New York: Francis Nicols.

Carvalho, P. C. (1998) - O forum de Aeminium. Lisboa: Instituto Português de Museus.

Carvalho, P. C. (2003) - "O templo romano de Nossa Senhora das Cabeças (Orjais, Covilhã) e a sua integração num território rural”. Conimbriga. Coimbra. 42, p. 153-182.

CARvalho, P. C. (2005) - "Identificação e representação espacial das capitais de civitates da Beira Interior". Lusitanos e romanos no Nordeste da Lusitânia. Actas das 2. as Jornadas de Património da Beira Interior. Guarda: Centro de Estudos Ibéricos, p. 155-169.

Carvalho, P. C. (2006) - Cova da Beira: ocupação e exploração do território na época romana. Coimbra. Dissertação de Doutoramento apresenta à Universidade de Coimbra.

Correia, V. (1928) - “O domínio romano”. In: Peres, D. \& Cerdeira, E. (dir.), História de Portugal. Barcelos: Portucalense Editora. p. 217-290.

Curado, F. P. (1988-94) - "A propósito de Conimbriga e Coniumbriga". Gaya. Actas do I Congresso Internacional sobre o rio Douro (1986). Vila Nova de Gaia. 6, p. 213-234.

Curado, F. P. (2004) - “A Martin Calvo e aos povoadores do Fundão". Eburobriga. Fundão. 2, p. 77-115.

Curado, F. P. (no prelo) - "Reflexões em torno do terminus augustalis dito de Peroviseu”. Eburobriga. Fundão. 4.

FERNANDES, L. da S. (2002) - “De suo: o registo epigráfico da impensa na Lusitânia”. Mathesis. Viseu. 11, p. 9-41.

FERNANDES, L. S., et alii (2006) - "Vicus e castellum na provincia Lusitania: notas epigráficas e arqueológicas”. Conimbriga. Coimbra. 45, p. 165-198.

FERreirA, A. P. (2000) - "Sobre a dispersão dos Tapori: algumas notas de reflexão". Conimbriga. Coimbra. 39, p. 153-189.

FLóREZ, H. (1786²) - España sagrada: Theatro geographico-historico de la iglesia de España, Tomo XIV. Madrid: Oficina de Pedro Marin.

Frade, H. (1990) - "Novos elementos sobre o templo romano de Almofala". Conimbriga. Coimbra. 29, p. 91-101.

Frade, H. (1993-94) - "A torre de Centum Cellas (Belmonte): Uma villa romana". Conimbriga. Coimbra. 32-33, p. 87-106

Frade, H. (1996) - "La Torre de Centum Cellas (Lusitanie) et sa région: quelques reseignements sur l'organisation de l'espace". L'Africa romana. XII Convegno internazionale di studio su "l'Africa romana" (Olbia, 12-15 dicembre 1996). Sassari, p. 885-890.

Frade, H. (2002) - Centum Cellas: Uma villa romana na Cova da Beira. Coimbra. Dissertação de mestrado apresentada à Universidade de Coimbra. 
Frade, H. (2005) - “A Torre de Centum Celas, uma villa, uma família, quatro séculos". Lusitanos e romanos no Nordeste da Lusitânia. Actas das 2. as Jornadas de Património da Beira Interior. Guarda: Centro de Estudos Ibéricos, p. 251-265 .

GARCIA, J. M. (1991) - Religiões antigas de Portugal. Lisboa: Imprensa Nacional Casa da Moeda.

García Iglesias, L. (1973) - Epigrafía romana de Augusta Emerita. Madrid (tese de doutoramento inédita).

Gimeno Pascual, H. (1997) - “Obras de reedificación del puente de Segura”. Conimbriga. Coimbra. 36, p. 191-200.

Gorges, J.-G. (1979) - Les villas hispano-romaines. Paris: Diff. De Boccard.

Guerra, A. (1995) - Plínio-o-Velho e a Lusitânia. Lisboa: Colibri.

GuERrA, A. (1998) - Nomes pré-romanos de povos e lugares do Ocidente Peninsular. Lisboa. Dissertação de Doutoramento apresentada à Universidade de Lisboa. HERnÁNDEZ GuERRA, L. (2001) - Epigrafía de época romana de la provincia de Salamanca. Valladolid: Centro Buendía - Universidad de Valladolid.

Hurtado de SAn Antonio, R. (1976) - "Identificación de los municipia estipendiarios que sufragaron el puente romano de Alcántara”. Revista de Estudios Extremeños. Cáceres. 32, p. 605-618.

LAMBrino, S. (1956) - "Les inscriptions latines inédites du Musée Leite de Vasconcellos". O Arqueólogo Português. Lisboa. Nova série, 3, p. 5-73.

LEAL, A. B. P. (1873) - Portugal antigo e moderno, vol. II. Lisboa: Livraria Editora Matos Moreira e C.ia.

LEAL, A. B. P. (1874) - Portugal antigo e moderno, vol. III. Lisboa: Livraria Editora Matos Moreira e C.ia.

Le Roux, P. (1994) - “Cités et térritoires en Hispanie: l'épigraphie des limites”. Mélanges de la Casa Vélazquez. Madrid. 30: 1, p. 37-51.

LEITÃo, M. (1981) - "Contributo para o estudo das divindades indígenas da Beira Baixa no período romano: duas novas aras". Trebaruna. Castelo Branco. 1, p. 51-58.

Machado, J. P. (1984) - Dicionário onomástico etimológico da língua portuguesa. Lisboa: Ed. Confluência.

Mantas, V. G. (1991) - “A rede viária do convento Escalabitano”. Symposium sobre la red viaria en la Hispania romana (Zaragoza, 24 al 26 de septiembre de 1987). Zaragoza: Institución Fernando el Católico, p. 219-239.

Mantas, V. G. (1992) - "Teledetecção e vias romanas". In Jornadas sobre Teledetección y Geofísica aplicadas a la Arqueología (Mérida, 1987). Madrid: Ministerio de Cultura, p. 165-174.

Mantas, V. G. (1993) - “A rede viária romana do território português”. In MedinA, J. (dir.) - História de Portugal, II. O mundo luso-romano. Alfragide: Ediclube, p. 213-230.

Mantas, V. G. (1998) - "O espaço urbano nas cidades do norte da Lusitânia". In Rodríguez Colmenero, A. (coord.) - Ls orígenes de la ciudad en el Noroeste hispánico: Actas del Congreso Internacional (Lugo, 15-18 de Mayo 1996), I. Lugo: Diputación provincial, p. 355-391. 
Monteiro, J. A. (1974) - "Término de Peroviseu na Lusitânia romana". Conimbriga. Coimbra. 13 , p. 57-62.

Moroni, G. (1845) - Dizionario di erudizione storico-ecclesiastica da S. Pietro sino ai nostri giorni, vol. XXXIII. Venezia: Tipografia Emiliana.

OsóRIo, M. (2002) - O povoamento romano do Alto Côa. Dissertação de Mestrado apresentada à Faculdade de Letras da Universidade de Coimbra. Coimbra.

OsóRIo, M. (2006) - O povoamento romano do Alto Côa. Guarda: Câmara Municipal. Pereira, V. (2005) - "Intervenção arqueológica na Póvoa do Mileu (Guarda)". Lusitanos e romanos no Nordeste da Lusitânia. Actas das 2. as Jornadas de Património da Beira Interior. Guarda: Centro de Estudos Ibéricos, p. 229-248.

Perestrelo, M. S. (2003) - A romanização da bacia do rio Côa. Vila Nova de Fôz-Coa: Parque Arqueológico do Vale do Côa.

Proença Jr., F. T. (1910) - Arqueologia do distrito de Castelo Branco. Leiria: Typ. Leiriense.

PRÓSPER, B. M. (2002) - Lenguas y religiones prerromanas del occidente de la Península Ibérica. Salamanca: Ed. Universidad.

RESENDE, A. de (1593) - De antiquitatibus Lusitaniae. Évora: Martim de Burgos.

Rodrigues, A. V. (1957-58) - “A propósito de uma lápide do Mileu (Guarda)”. Humanitas. Coimbra. 9-10, p. 164-166.

Rodrigues, A. V. (1962a) - "Elementos para o estudo da romanização nos Montes Hermínios, I. As escavações da Póvoa do Mileu - Guarda”. Lucerna. Porto. 2, p. 58-69.

Rodrigues, A. V. (1962b) - “A torre «Centum Celas», pretório de um acampamento romano?”. Revista de Guimarães. Guimarães. 72, p. 317-325.

Rodrigues, A. V. (1977) - Monografia artística da Guarda. Anadia: Cisial.

Rodrigues, M. A. G. C. (1982) - Ferro, Cova da Beira: Estudos arqueológicos. Braga. RoldÁn Hervás, J. M. (1968-69) - "Fuentes antiguas para el estudio de los Vettones". Zephyrus. Salamanca. 19-20, p. 73-106.

SAA, M. (1964) - As grandes vias da Lusitânia: o itinerário de Antonino Pio. Lisboa: Tipografia da Sociedade Astória.

Schulten, A. (1955) - Iberische Landeskunde: Geographie des antike Spanien, Band I. Strasbourg: Heitz.

Schulten, A. (1957) - Iberische Landeskunde: Geographie des antike Spanien, Band II. Baden-Baden: Valentin Koerner.

Silva, A. J. M.; Carvalho, P. C. (2004) - “À porta de uma quinta do alto império: Resultados preliminares do estudo intra-sítio do assentamento romano de "Terlamonte I" (Teixoso, Covilhã)". Conimbriga. Coimbra. 43, p. 99-147.

SouzA, V. de (1990) - Corpus signorum imperii romani. Portugal. Coimbra: Instituto de Arqueologia da Faculdade de Letras de Coimbra.

TIR J-29 = Tabula Imperii Romani, Hoja J-29: Lisboa. Madrid: IGN - CSIC - Ministerio de Cultura, 1991.

TIR K-29 = Tabula Imperii Romani. Hoja K-29: Porto. Madrid: IGN - CSIC - Ministerio de Cultura, 1995.

Tovar, A. (1974) - Iberische Landeskunde: Baetica. Baden-Baden: Valentin Körner. 
Tovar, A. (1976) - Iberische Landeskunde: Lusitanien. Baden-Baden: Valentin Körner.

Tovar, A. (1989) - Iberische Landeskunde: Las tribus y las ciudades de la antigua Hispania, Tomo 3 - Tarraconensis. Baden-Baden: Valentin Körner.

VAsConcellos, J. L. de (1934) - "Antiguidades do concelho da Covilhã". Biblos. Coimbra. 101, p. 25-28.

VAsCONCELlos, J. L. de (1959³) - Lições de filologia portuguesa. Rio de Janeiro: Livros de Portugal.

VAZ, J. L. I. (1977) - "Inscrições romanas do Museu do Fundão". Conimbriga. Coimbra. 16, p. 5-31.

VAZ, J. L. I. (1997) - A civitas de Viseu, espaço e sociedade. Coimbra: Comissão de Coordenação da Região Centro. 


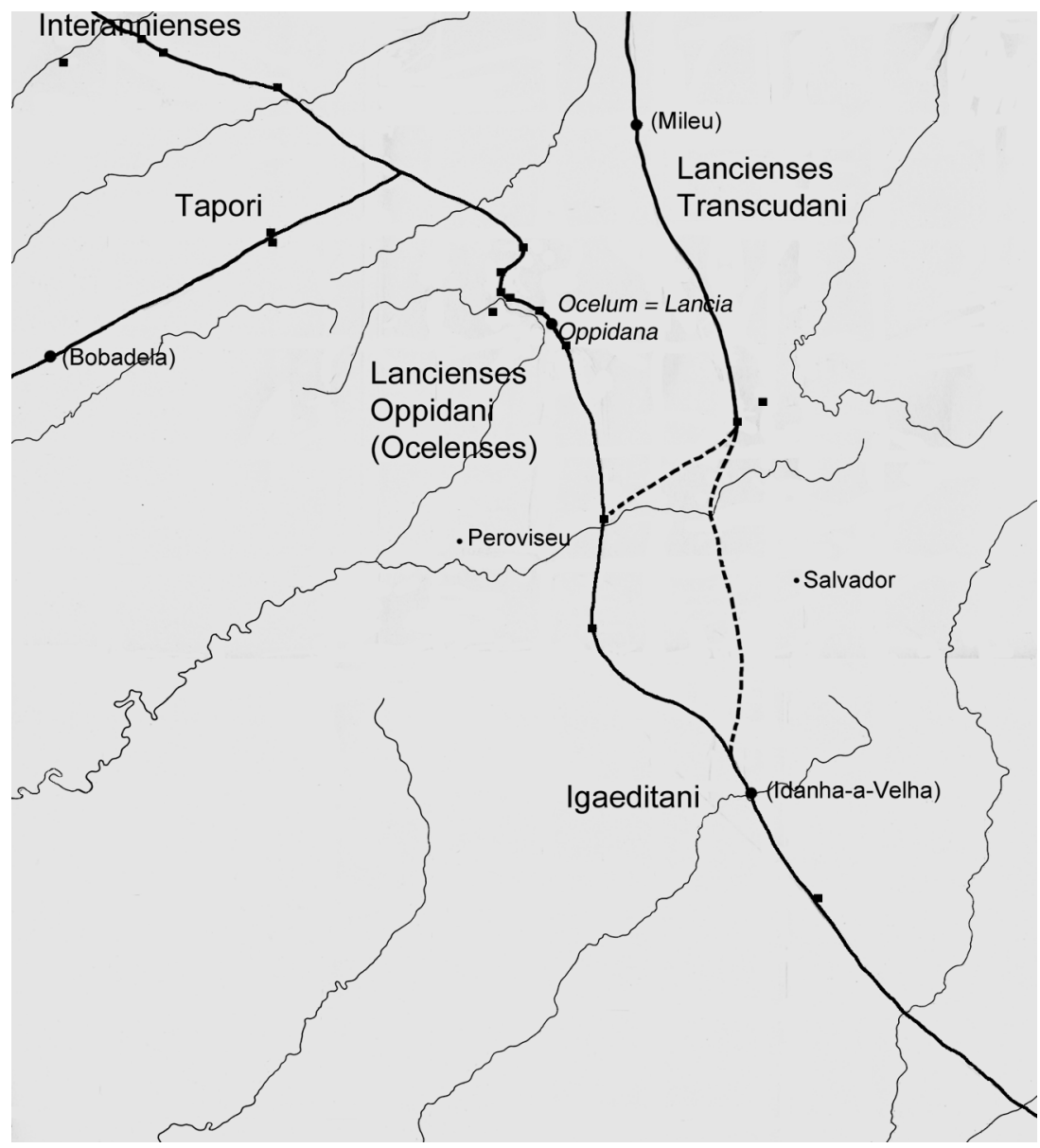

Mapa da região em análise, com os principais eixos viários. 
EST. II

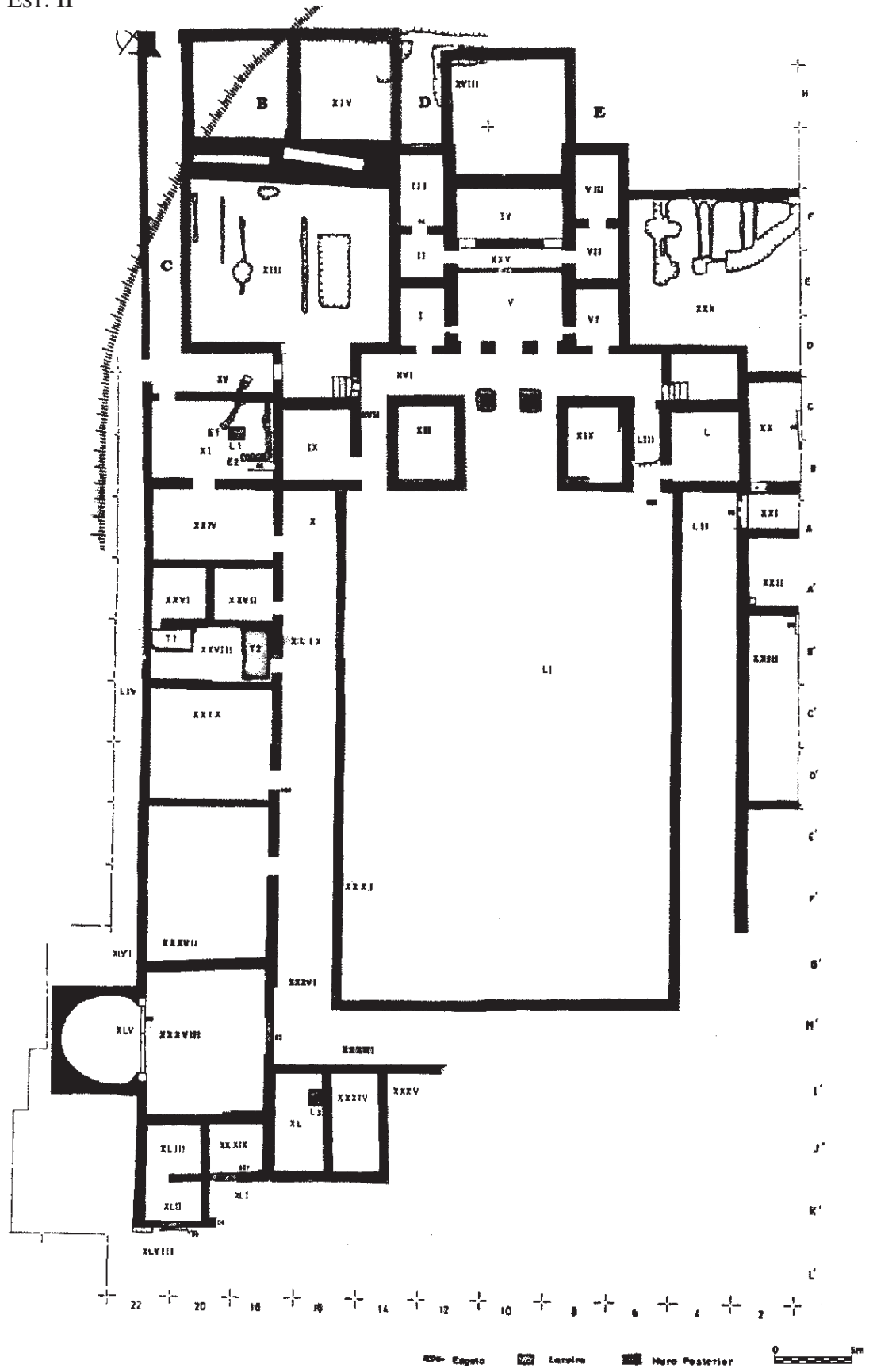

Planta das estruturas de Centum Celas, segundo Helena Frade

(2005, p. 261). 


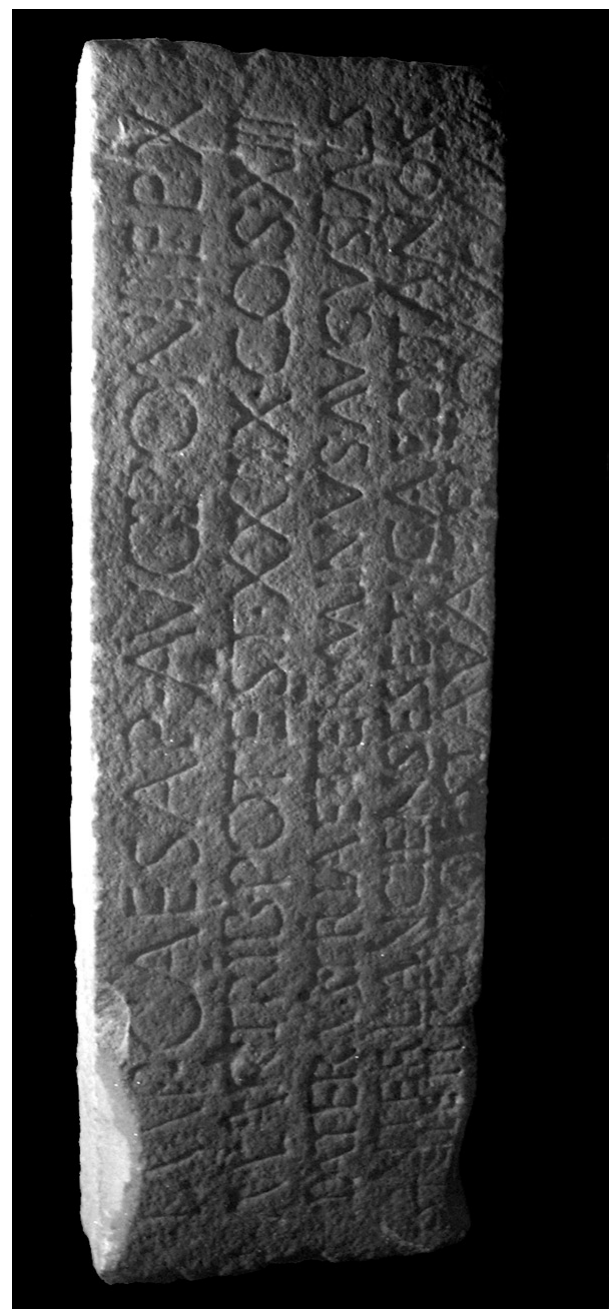

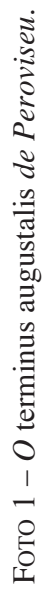

